\title{
St. Vincent and the Grenadines: 2003 Article IV Consultation-Staff Report; Staff Supplement; Public Information Notice on the Executive Board Discussion; and Statement by the Executive Director for St. Vincent and the Grenadines
}

Under Article IV of the IMF's Articles of Agreement, the IMF holds bilateral discussions with members, usually every year. In the context of the 2003 Article IV consultation with St. Vincent and the Grenadines, the following documents have been released and are included in this package:

- the staff report for the 2003 Article IV consultation, prepared by a staff team of the IMF, following discussions that ended on November 7, 2003, with the officials of St. Vincent and the Grenadines on economic developments and policies. Based on information available at the time of these discussions, the staff report was completed on April 1, 2004. The views expressed in the staff report are those of the staff team and do not necessarily reflect the views of the Executive Board of the IMF.

- a staff supplement of May 3, 2004 updating information on recent developments.

- a Public Information Notice (PIN) summarizing the views of the Executive Board as expressed during its May 5, 2004 discussion of the staff report that concluded the Article IV consultation.

- a statement by the Executive Director for St. Vincent and the Grenadines.

The policy of publication of staff reports and other documents allows for the deletion of market-sensitive information.

To assist the IMF in evaluating the publication policy, reader comments are invited and may be sent by e-mail to publicationpolicy@imf.org.

$$
\begin{gathered}
\text { Copies of this report are available to the public from } \\
\text { International Monetary Fund • Publication Services } \\
70019^{\text {th }} \text { Street, N.W. • Washington, D.C. 20431 } \\
\text { Telephone: (202) 623-7430 • Telefax: (202) 623-7201 } \\
\text { E-mail: publications@imf.org • Internet: http://www.imf.org }
\end{gathered}
$$

Price: $\$ 15.00$ a copy

\section{International Monetary Fund Washington, D.C.}




\title{
INTERNATIONAL MONETARY FUND
}

\section{ST. VINCENT AND THE GRENADINES \\ Staff Report for the 2003 Article IV Consultation}

\author{
Prepared by the Staff Representatives for the 2003 Consultation with \\ St. Vincent and the Grenadines
}

Approved by José Fajgenbaum and Matthew Fisher

April 1, 2004

\begin{abstract}
Discussions. A staff team, comprising A. Salehizadeh (Head), J. Chai, P. Kufa, and Y. Wu (all WHD), held discussions in Kingstown during October 27-November 7, 2003, with D. Robinson (WHD) joining the mission on November 3. The team was assisted by staff of the Eastern Caribbean Central Bank (ECCB) and the Caribbean Development Bank (CDB). I. Bennett and R. Campbell (OED) participated in the final meetings. The team met with the prime minister (who is also the Minister of Finance), the Director General of Finance, other senior government officials, the leader of parliamentary opposition, and representatives of labor, business, and the financial sector.
\end{abstract}

Exchange system. St. Vincent and the Grenadines, with a population of about 110,000 and per capita GDP of US\$3,300, is one of eight Eastern Caribbean countries and territories comprising the Eastern Caribbean Currency Union (ECCU), of which six are Fund members. ECCU countries and territories share a common central bank (the ECCB) and the common currency (E.C. dollar) is pegged to the U.S. dollar. St. Vincent and the Grenadines has accepted the obligations of Article VIII, Sections 2, 3, and 4, and maintains an exchange system free of restrictions on payments and transfers for current international transactions. Fund relations are summarized in Appendix I.

Political situation. St. Vincent and the Grenadines is a parliamentary democracy. The Unity Labour Party assumed power following the March 2001 elections, in which it defeated the National Democratic Party (in power since 1984) by winning 12 out of 15 elected seats in parliament. Elections are due no later than March 2006.

Previous Article IV consultation. At the conclusion of the consultation on January 27, 2003, Directors expressed concern about the fiscal deterioration and rising public sector debt. They urged wage restraint, a curb in other recurrent expenditures, prioritization of public sector investments with a focus on growth promotion and poverty reduction, a broadening of the tax base, and removal of tax exemptions. Directors cautioned against expensive foreign borrowing and encouraged the authorities to improve the management of public enterprises. Directors urged bolstering the health of the financial system by restructuring the state-owned commercial bank and improving the prudential framework of the nonbank sector.

Statistics. The statistical base has improved in recent years, but weaknesses remain in certain areas (for example the labor market, national accounts, and balance of payments statistics) that hinder effective surveillance (Appendix IV). 


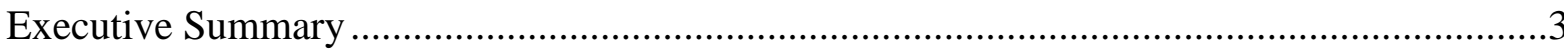

I. Background and Recent Economic Developments..............................................4

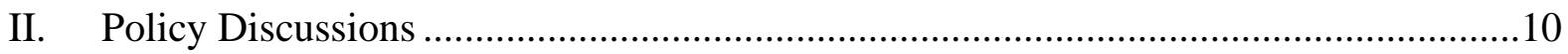

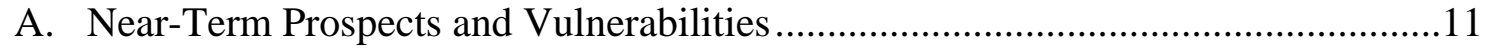

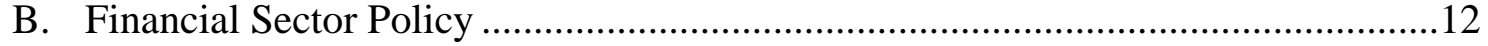

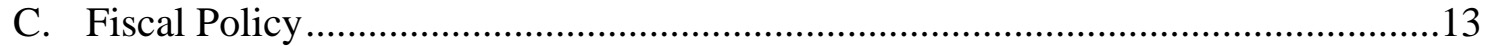

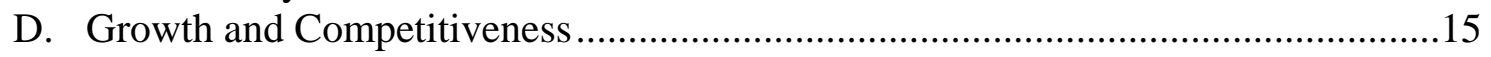

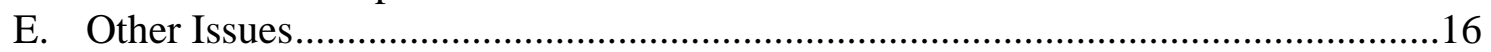

F. Medium-Term Outlook and Debt Sustainability Analysis ...................................16

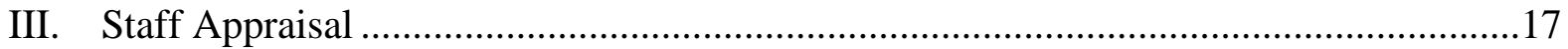

Boxes

1. Poverty Reduction Strategy .................................................................................20

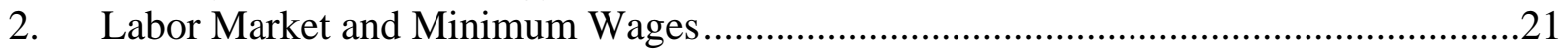

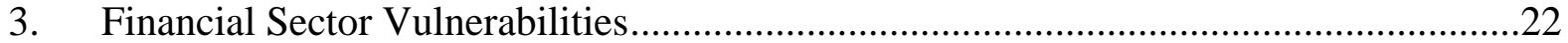

Figures

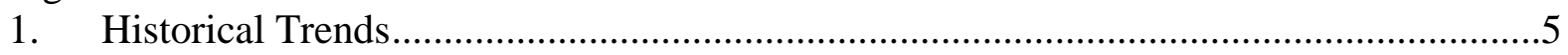

2. Exchange Rate Developments ......................................................................... 19

Tables

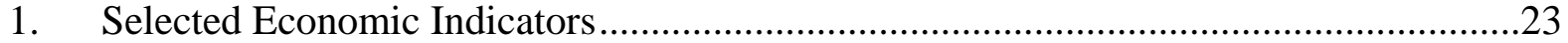

2. Summary of Consolidated Public Sector Operations..................................................24

3. Summary of Central Government Operations ........................................................25

4. Public Sector Debt ............................................................................................26

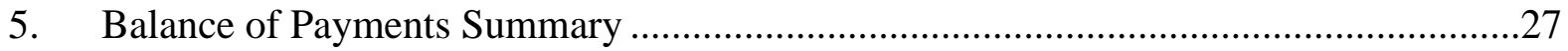

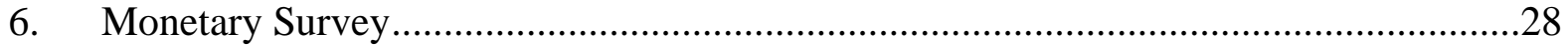

7. Indicators of External and Financial Vulnerability .................................................29

8. Comparative Economic Performance .........................................................................30

9. Compliance with Proposed Central Government Fiscal Guidelines..............................31

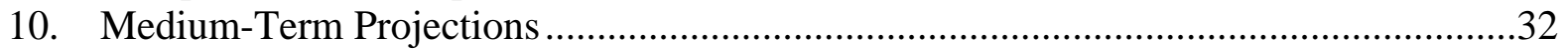

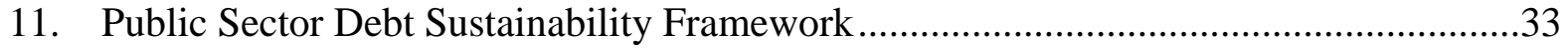

12. External Debt Sustainability Framework ................................................................34

Appendices

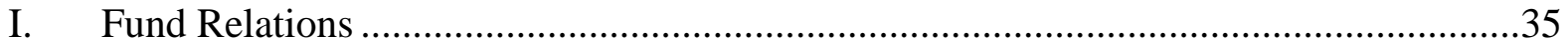

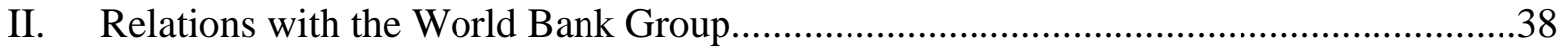

III. Relations with the Caribbean Development Bank ..................................................40

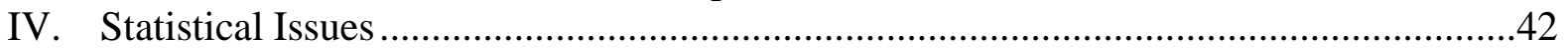




\section{EXECUTIVE SUMMARY}

\section{Recent developments}

- St. Vincent and the Grenadines enjoyed relatively high economic growth through most of the 1990s, but growth has slowed in recent years. Following stagnation in 2001, a moderate recovery started in 2002 and the economy is estimated to have grown by about $1 \frac{1}{2} 2$ percent a year in 2002-03. Growth has been supported by a rebound in agricultural production and expansionary fiscal policies, including large public sector investments, while private sector activity has been weak.

- The overall fiscal stance in 2002-03 was relaxed, with fiscal stimulus coming through a strong increase in investment partly offset by a higher current surplus of the central government. The overall deficit of the nonfinancial public sector doubled to $3 \frac{1}{2}$ percent of GDP a year over this period largely due to higher capital spending. As a result, public sector debt increased to more than 71 percent at end-2003. At the same time, central government current revenue rose sharply (due to significant improvements in broadening the tax base, removing tax concessions, and strengthening tax administration, as well as one-off factors), while government wages were frozen and nonwage current expenditure was kept under tight control.

\section{Policy discussions}

- The authorities should revert to their prudent fiscal policies and continue to contain current spending. The public sector investment program should focus on projects that are aimed at enhancing the economy's growth potential and are largely financed on concessional terms to ensure debt sustainability.

- Given the unusual stress in the ECCU region, the authorities should formulate a contingency plan in the event that a crisis occurs. The plan should include fiscal measures to reduce (or at least rephase) financing needs.

- The authorities should address the weaknesses in the banking system's regulatory and supervisory framework which were identified by the ECCU FSAP exercise. In particular, they should develop expeditiously a clear strategy for the state-owned National Commercial Bank, which has a high nonperforming loans ratio.

- $\quad$ Reforms in several areas are needed to enhance the growth potential. Key hindrances to growth include weak institutional capacity, labor market rigidities, small size of the economy, and high cost of doing business. Efforts to strengthen public institutions, improve the supply of skilled labor, enhance access to global markets and deepen regional integration, and improve the efficiency of public enterprises including utilities should be intensified. 


\section{BACKGROUND AND RECENT ECONOMIC DEVELOPMENTS}

\section{Developments during the 1990s}

\section{St. Vincent and the Grenadines} enjoyed relatively high economic growth through most of the 1990s, but growth has slowed since the late 1990s. Real GDP growth averaged $3 \frac{1}{2}$ percent a year for the decade; excluding bananas (the key traditional export crop), growth averaged $41 / 4$ percent a year (Figure 1). The economy underwent a major structural transformation in the 1990s as the share of agriculture in

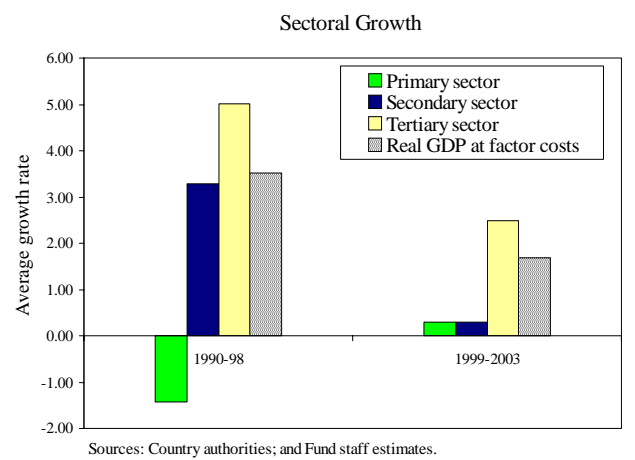
GDP declined by about 10 percentage points (reflecting the retrenchment of the banana industry), ${ }^{1}$ while that of services increased by the same rate, with tourism becoming the largest foreign exchange earner. As the economy is vulnerable to external factors (such as growth in the United States and the United Kingdom-the origin of most tourists-and weather-related shocks such as hurricanes and droughts), real GDP growth during the 1990s showed significant yearly variations (between -2.9 percent to 8.3 percent). Unemployment has remained high (estimated at about 21 percent). ${ }^{2}$

\section{To reduce growth volatility, since the mid-1990s the government has} attempted to implement an economic diversification program supported by major public investments. ${ }^{3}$ Reflecting the concern with the social implications of rising rural unemployment, the cornerstone of the economic diversification program has been structural reforms in the agricultural sector, aimed not only at promoting non-banana crops, but also at increasing the productivity of the banana sector. Although progress has been made on irrigation projects and on identifying more productive banana farmers, the implementation of other aspects of the diversification program has been slow.

\footnotetext{
${ }^{1}$ Banana production declined from a peak of around 80,000 tons in 1990 to about 37,000 tons in 2002.

2 This estimate, based on the results from the 2001 census, represents an increase of about 1 percentage point from the preceding official estimate based on the 1991 census.

${ }^{3}$ During the 1990 s, public sector capital spending averaged $11 \frac{1}{2}$ percent of GDP a year, 70 percent of which was undertaken by the central government, and the remainder by the public enterprises.
} 
Figure 1. St. Vincent and the Grenadines: Historical Trends

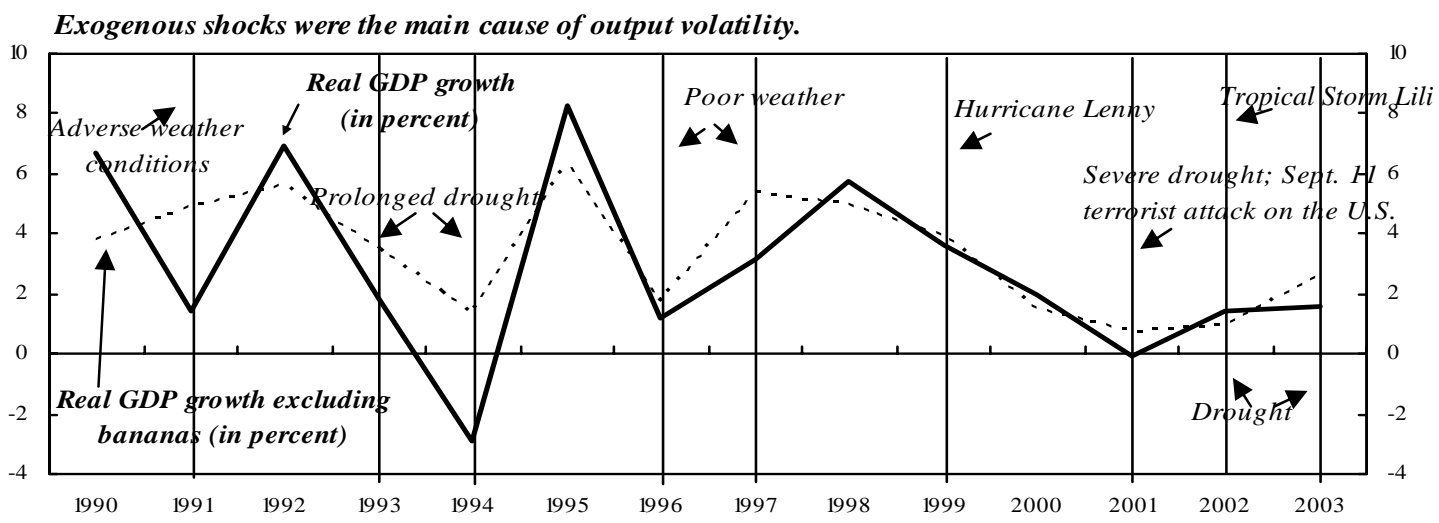

The public finances were generally kept under control;

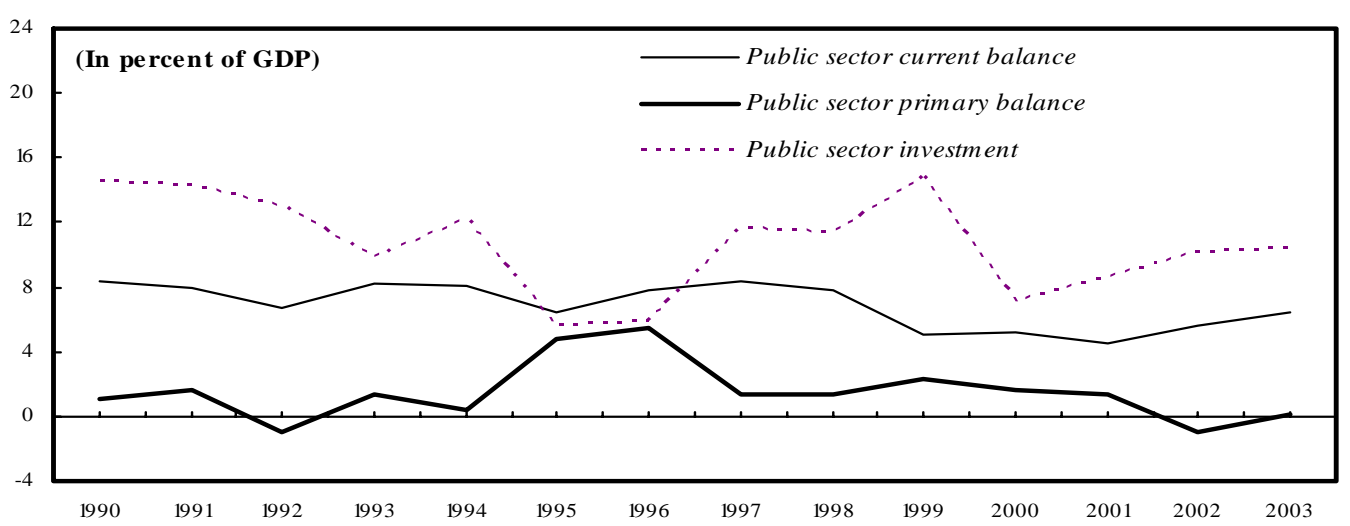

however, the public debt to GDP ratio rose sharply in1999. ${ }^{4}$

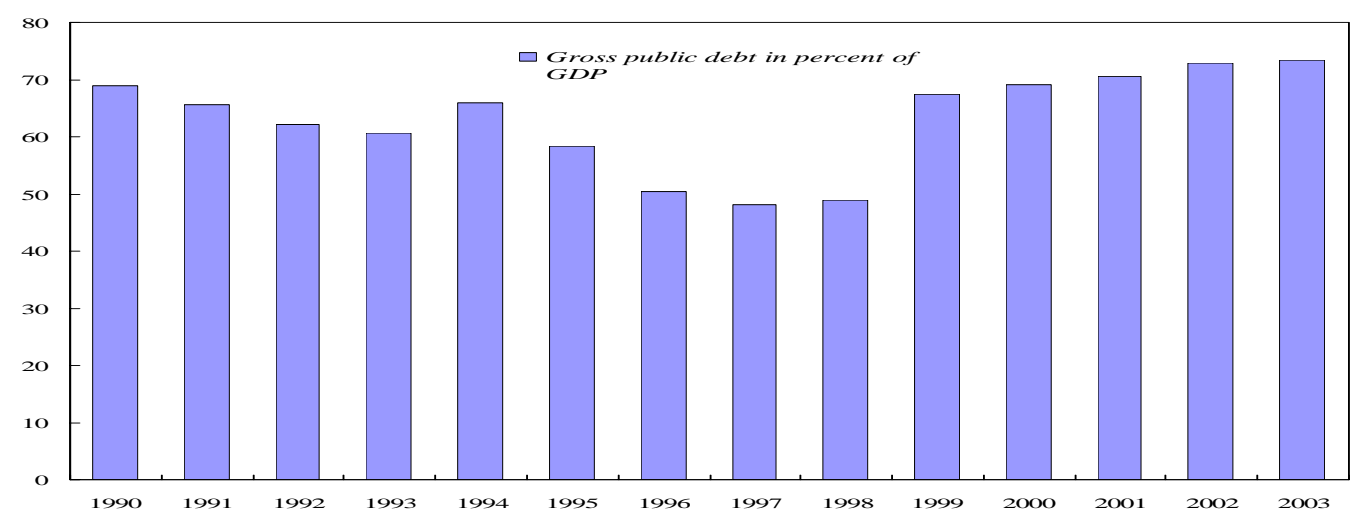

Sources: Country authorities; and Fund staff estimates.

${ }^{4}$ See Paragraph 3 for explanation. 
3. St. Vincent and the Grenadines had moderate levels of public sector debt and debt service during the 1990s. Total public sector debt averaged less than 60 percent of GDP during 1990-98 (of which about one half was external debt), and there was a net reduction of debt during the period. However, in 1999, the government assumed a large private external loan, raising the public sector debt to 66 percent of GDP (from 49 percent in 1998). ${ }^{5}$ During the decade, external public debt service averaged about 5 percent of exports of goods and services and less than 10 percent of central government's current revenue.

4. Despite the high frequency of natural disasters, the fiscal deficits in the 1990s were modest. During the decade, the current account surplus (savings) of the nonfinancial public sector (NFPS) ${ }^{6}$ averaged 71/2 percent of GDP a year, while the overall deficit of the sector was 1 percent of GDP. ${ }^{7}$ One half of the NFPS savings was accounted for by the central government, while the other half was shared equally between the National Insurance Scheme (NIS) and the public enterprises (mainly the electricity and water companies).

\footnotetext{
${ }^{5}$ In the early 1990s, the government participated in a joint venture with the private sector for the construction of a marina (Ottley Hall project). However, the project failed, the private sector partners defaulted on the loan, and the government assumed the loan which equaled 171/2 percent of 1999 GDP.

${ }^{6}$ The nonfinancial public sector includes the central government, the Kingstown Board, the National Insurance Scheme (NIS), and 10 public enterprises.

${ }^{7}$ The central government overall deficit averaged 1.9 percent of GDP, while the NIS had an overall surplus averaging 1.6 percent of GDP and the public enterprises had an average deficit of $3 / 4$ percent of GDP.
} 
5. Since 1990, the St. Vincent and Grenadines' economy has generally performed better than the ECCU average.

Real GDP growth, central government balances, and public sector debt have been at levels better than the ECCU averages. A notable exception is the government wage bill (as a percent of GDP), which has been higher than the average for the ECCU.

\section{With GDP per capita at the lower}

St. Vincent and the Grenadines: Comparative Economic Performance: 1990-2002

\begin{tabular}{lrr}
\hline & $\begin{array}{r}\text { St. Vincent and } \\
\text { the Grenadines }\end{array}$ & ECCU \\
\hline \multicolumn{1}{c}{ (In percent of GDP) } & 3.0 & 2.2 \\
\hline Real GDP growth at factor cost (percent) & 3308 & 4995 \\
GDP per capita (US\$; 2002 est.) & 3.2 & 2.7 \\
Tourism growth, stay-overs (percent) & 13.4 & \\
& -2.0 & 12.3 \\
Central government wage bill & 3.3 & -3.8 \\
Central government overall balance & -0.2 & 1.0 \\
Central government current balance & 53.8 & -1.0 \\
Central government primary balance & 37.1 & 69.4 \\
Total public sector debt & 48.7 \\
Public sector external debt & & \\
\hline
\end{tabular}

Source: Country authorities end of the ECCU average, the government has placed poverty alleviation at the forefront of its economic program. An Interim Poverty Reduction Strategy Paper (I-PRSP) has been prepared, which is intended to serve as a blueprint for achieving the Millennium Development Goal of halving the level of poverty by 2015 (Box 1).

\section{Recent developments}

\section{Following stagnation in 2001, a} moderate recovery started in 2002 . The economy is estimated to have grown about $1 \frac{1}{2}$ percent a year in 2002-03 (Table 1 ). Growth has been supported by a rebound in agricultural production and countercyclical fiscal policies, including large public sector investments. Private sector wage increases have averaged 4 percent during 1999-2003, and after a long period of no change, minimum wages were increased in 2003 (Box 2). Inflation has remained in the low single digits, reflecting the monetary discipline of the currency union. The 12-month inflation rate is projected at $1 \frac{1}{2}$ percent in December 2003.

\section{The overall fiscal stance in 2002-03} was relaxed, with the fiscal stimulus coming through a strong increase in investment partly offset by a higher current surplus of the central government. The overall deficit of the NFPS doubled from its 2001 level to $3 \frac{1}{2}$ percent of GDP a year over this period as capital spending - by public enterprises on power and water projects as well as by the central government-increased by an average of

\begin{tabular}{lrrr}
\multicolumn{4}{c}{ Selected Economic Indicators, 2001-03 } \\
\hline & 2001 & 2002 & 2003 \\
\hline & (Annual percentage changes) & \\
\hline & -0.1 & 1.4 & 1.6 \\
Real GDP (factor cost) & -0.6 & 0.4 & 1.5 \\
Consumer prices, end of period & 0.5 & -7.2 & -8.6 \\
Real effective exchange rate 1/ & 2.9 & 2.1 & -5.2 \\
External terms of trade & & & \\
& (In percent of GDP) \\
Gross capital formation & 29.7 & 30.0 & 33.7 \\
Of which: public investment & 8.6 & 10.1 & 10.5 \\
Gross national savings & 18.8 & 20.4 & 17.6 \\
Of which: public savings & 4.5 & 5.6 & 6.7 \\
\hline Sources: Country authorities and Fund staff estimates. \\
1/ An increase (decrease) indicates an appreciation (depreciation).
\end{tabular}
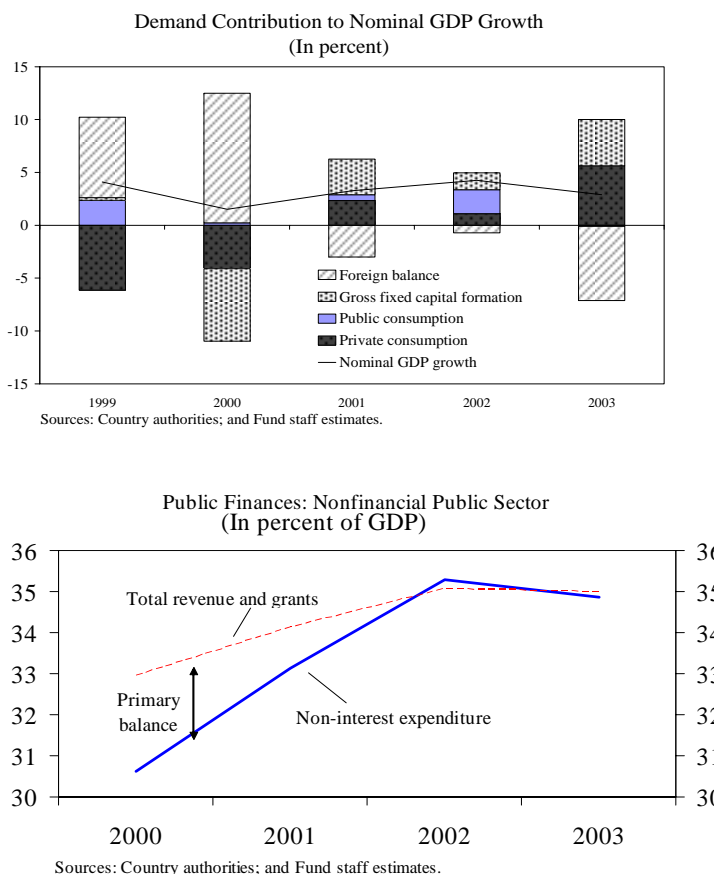
nearly 2 percentage points of GDP relative to its 2001 level (Tables 2 and 3). As a result, public sector debt increased to more than 71 percent at end-2003 (Table 4).

9. In 2002-03, central government current revenue rose sharply while current expenditure was held under close control. Significant improvements in broadening the tax base, removing tax concessions, and strengthening tax administration, as well as oneoff factors have contributed to the increase in revenue. ${ }^{8}$ At the same time, current expenditure remained largely unchanged, as government wages were frozen and nonwage current expenditure was kept under tight control. ${ }^{9}$

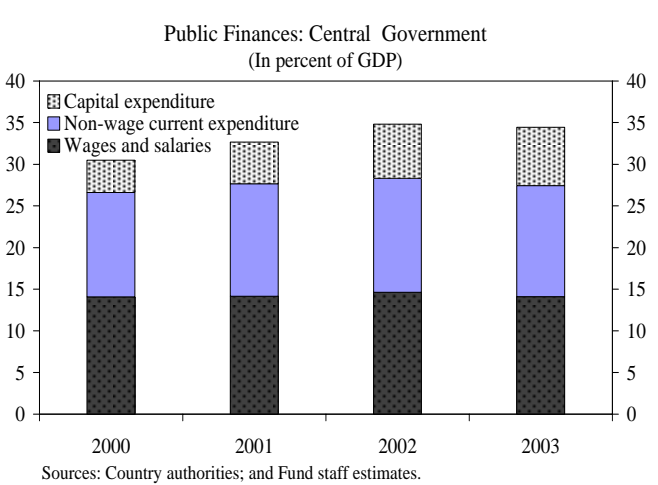

10. The external current account deficit widened sharply in 2003, driven by a temporary spike in investment-related imports (Table 5). The large rise $\left(6 \frac{1}{2}\right.$ percent of GDP) in the current account deficit in 2003 was due to a 13 percent increase in imports reflecting: (i) strong investment in the telecommunication sector and the associated imports of equipment and cell phones, following the liberalization of

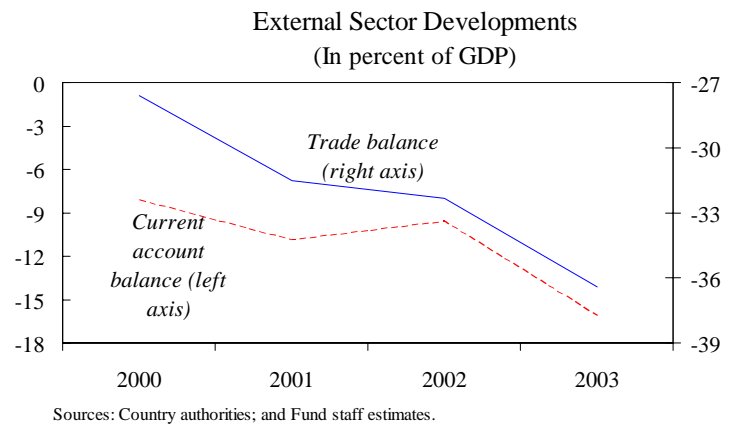
the telecommunication sector; (ii) imports of machinery, equipment, and building materials largely related to public sector investment; and (iii) the impact of higher international petroleum prices. Tourism receipts have risen since the September 11, 2001 attacks, but are estimated to have increased only marginally in 2003, as uncertainties before the Iraq war affected international travel during the first quarter of the year (the main tourist season). About three-quarters of the current account deficit during 2000-03 was financed by direct investment, while the remainder was financed by public sector borrowing.

\footnotetext{
${ }^{8}$ Current revenue was 3 percent of GDP higher in 2003 than in 2000. The one-off factors contributing to the revenue increase included around 1 percent of GDP in duty collections on imports of cell phones in 2003 (see paragraph 10).

${ }^{9}$ Current expenditure in 2003 was about $1 / 2$ percent of GDP higher than in 2000 . The wage bill increased by $1 / 2$ percent of GDP in 2002, reflecting new hiring as well as a 4 percent bonus that was granted to civil service employees in December 2002 in lieu of a general salary increase.
} 
11. Reflecting credit developments, the expansion of monetary aggregates slowed in 2003. Banking system net credit to the government, which had almost doubled in 2002, fell sharply in 2003 as the government financed its deficit externally (Table 6). At the same time, the growth in private sector credit declined as private sector activity remained stagnant. Thus, after rising by $81 / 3$ percent in 2002 , broad money is estimated to have increased by about 3 percent in 2003. As a consequence of the resulting excess liquidity, commercial banks continued to build up their net foreign asset positions and lowered slightly their deposit rates in 2003 (except for the rate on saving deposits), while keeping lending rates basically unchanged. ${ }^{10}$

\section{Prudential indicators provide mixed signals about the strengths of the} banking system, but point to significant weakness of the state-owned bank which holds about a third of banking system assets. ${ }^{11}$ Banks' loan portfolios remain concentrated on personal lending and their profitability is low relative to the ECCU average. The ratio of nonperforming loans (NPL) to total loans was around 13 percent at end-June 2003 (Table 7), slightly below the ECCU average (14 percent). While the branches of foreign banks had an average NPL ratio of $4 \frac{1}{2}$ percent, this ratio for the locally incorporated banks, which account for about 60 percent of banking system assets, stood at 19 percent, with their provision for loan losses as a share of total nonperforming loans amounting to 25 percent. The ratios for locally incorporated banks largely reflect those of the state-owned National Commercial Bank (NCB).

\section{Regulation and supervision of the offshore sector has been strengthened, but} much still remains to be done. ${ }^{12}$ As a result of enhanced regulation and supervision, St. Vincent and the Grenadines was removed from the OECD's list of tax havens in 2002 and from the Financial Action Task Force (FATF) list of noncooperative countries and

${ }^{10}$ The rate on saving deposits was not lowered because it is subject to the ECCB interest rate floor of 3 percent.

${ }^{11}$ The commercial banking system comprises four banks (the NCB, one subsidiary of a regional-non-ECCU—bank, and two branches of foreign banks). The subsidiary of the regional bank is locally incorporated and is classified in the ECCB statistics as a local bank.

12 As of end-September 2003, the offshore financial sector comprised 6,695 international business companies (IBCs), 394 trusts, 11 banks, 5 insurance companies, 9 mutual funds/asset managing companies, and 40 registered agents. 
territories (NCCTs) in June 2003. ${ }^{13}$ The short-term consequence of the strengthened regulation and supervision has been a sharp reduction in the number of offshore banks (which stood at 11 as of end-September 2003, compared with 44 at end-

December 2001). ${ }^{14}$ Despite improvements, the prudential supervision of the offshore sector remains less robust than that of the domestic financial sector.

14. Progress has been made on structural reforms. Steps have been taken to diversify the economy and enhance its external competitiveness, attract foreign investment, improve the budgetary process, and strengthen the regulation of the financial sector.

- Diversification: The restructuring of the banana sector has continued, and efforts to diversify into other crops and agro-processing have advanced. These efforts include conducting research and training of farmers for the development of nonbanana crops, acquiring relevant technology, and improving marketing.

- Growth and competitiveness: Efforts have been made to promote foreign investment by, inter alia, establishing a one-stop investment shop and implementing training programs to improve labor skills.

- $\quad$ Fiscal management: The budgetary process has improved through the introduction of a three-year rolling budget and the concentration of the planning functions of line ministries in the ministry of finance and planning. There has also been progress in restructuring public enterprises as a result of establishing quarterly financial reviews and implementing strategic corporate plans.

- $\quad$ Financial sector supervision: An umbrella supervisory agency has been established recently, with a coordinating role for the expanding domestic financial system.

\section{Policy Discussions}

15. Over the past several years, the Fund policy advice to St. Vincent and the Grenadines has centered on the need to strengthen public finances. Other Fund recommendations have included the need to address data deficiencies and to draw a schedule for possible privatization of selected public enterprises. Implementation of

\footnotetext{
${ }^{13}$ Following the removal of the country from the FATF list of NCCTs, 154 new entities were registered during the third quarter of 2003, compared with 144 for the corresponding period in 2002.

${ }^{14}$ This reduction led to a drop in government revenue from this sector, despite an upward revision of fees. The government revenue from the sector during JanuarySeptember 2003 was EC\$1.9 million, compared with EC\$2.8 million in 2002.
} 
previous Fund advice has been mixed. Significant progress has been made in implementing measures to strengthen expenditure control and improve tax administration. However, overall macroeconomic policy has deviated from Fund recommendations, in part due to the impact of exogenous shocks and the need the authorities felt for pursuing more active countercyclical fiscal policy. In the structural area, while the authorities concur with Fund recommendations, progress has been limited in large part due to capacity constraints.

16. Discussions focused on the challenges facing the authorities in reinvigorating private sector growth while preserving macroeconomic stability. In this context, discussions covered near-term prospects and risks as well as the medium-term outlook. The authorities broadly agreed with the staff that the current strategy of government-led growth through large public sector investment can only provide a temporary boost to the economy as sooner or later a debt constraint will be encountered. They also agreed that policies should be geared toward preserving macroeconomic stability and ensuring fiscal sustainability over the medium term.

\section{The authorities believe that the currency board arrangement (CBA) has} provided a long period of price stability, and reiterated their commitment to its maintenance. The staff noted that pressures on the continued stability of the CBA are mounting, as several ECCB member countries face challenges similar to those faced by St. Vincent and the Grenadines but start from deeper fiscal imbalances and are accumulating substantial debts with stagnant growth. The authorities agreed that achieving the fiscal targets adopted by the ECCB's Monetary Council would provide reassurance of the consistency of fiscal positions within the CBA (Table 9). The mission noted that the adoption of these targets-enforced either on a regional basis via the ECCB (or any other relevant regional entity) or through national legislation, for example in the form of a fiscal responsibility law-would provide an important signal that national fiscal policies will seek to achieve these targets.

\section{A. Near-Term Prospects and Vulnerabilities}

18. A modest recovery is projected for the near-term, subject to substantial risks.

The outlook for 2004 is for real GDP to grow by $2-2 \frac{1}{2}$ percent but private sector activity is expected to remain weak. In addition to the usual risks related to volatility in the global economy, uncertainties in the tourism sector, and other potential exogenous shocks, the region as a whole is undergoing a period of unusual stress. As the countries in the region seek to resolve their situations, there is a possibility that events in one country could spill over into the other countries in the region. While the comparatively strong
Selected Economic Indicators, 2003-04

\begin{tabular}{|c|c|c|}
\hline & $\begin{array}{r}\text { Est. } \\
2003\end{array}$ & $\begin{array}{l}\text { Proj. } \\
2004\end{array}$ \\
\hline \multicolumn{3}{|c|}{ (Annual percentage changes, unless otherwise stated) } \\
\hline Real GDP (factor cost) & 1.6 & 2.4 \\
\hline External terms of trade & -5.2 & -0.8 \\
\hline Banana export earnings (in millions of U.S. dollars) & 12.0 & 16.2 \\
\hline Tourism expenditure (in millions of U.S. dollars) & 83.6 & 85.8 \\
\hline \multicolumn{3}{|l|}{ (In percent of GDP) } \\
\hline External current account & -16.1 & -13.3 \\
\hline Central government current balance & 4.1 & 3.6 \\
\hline Central government overall balance & -1.3 & -2.0 \\
\hline Public sector primary balance & 0.4 & 0.2 \\
\hline Gross public external debt & 50.5 & 45.0 \\
\hline Gross public debt & 71.0 & 67.1 \\
\hline
\end{tabular}


starting point of St. Vincent and the Grenadines provides additional room for maneuver in such an event, the staff strongly recommended the formulation of a contingency plan that should include fiscal measures to reduce financing needs. However, as the size of the gross financing needs of the government in the near-term is not large, the authorities did not see much risk and felt that they had sufficient flexibility on timing expenditures to withstand temporary funding disruptions. In this connection, they pointed to the continued decline in interest rates on recent government placements in the Regional Government Securities Market (RGSM).

\section{B. Financial Sector Policy}

\section{The authorities have begun addressing the weaknesses in the banking} system's regulatory and supervisory framework which were identified by the ECCU FSAP exercise (Box 3). ${ }^{15}$ To this end, the government has drafted amendments to the Banking Act and the ECCB Agreement Act, which are expected to be approved soon. ${ }^{16}$ The authorities have also given high priority to developing a clear strategy for the NCB, and have begun to take steps to restructure the bank, including by reorganizing its Board of Directors and changing its senior management, as well as selling its properties on a sale and lease back arrangement. The staff recommended that in the meantime, it will be important for the authorities and the ECCB to closely monitor the performance of the bank.

\section{The authorities are also taking steps to enhance the regulation and} supervision of the nonbank financial institutions (NBFI) and the offshore financial sector. The government has established an umbrella agency (Supervisory and Regulatory Unit) in the Ministry of Finance and Planning to regulate the activities of the NBFI sector, which has grown rapidly in recent years and accounts for 28 percent of total assets of the financial system. ${ }^{17}$ The authorities have requested technical assistance from the CARTAC to draft amendments to the International Financial Services laws, taking into

\footnotetext{
${ }^{15}$ The FSAP for the ECCU, which was conducted in September-October 2003, identified several weaknesses in the banking system that need to be addressed, including unacceptably high levels of nonperforming loans in indigenous banks, the uncertain quality of capital of these banks, and weaknesses in supervision of domestic and offshore financial sectors.

${ }^{16}$ These amendments were proposed by the ECCB to bring the banking laws more in line with international standards and to give the ECCB more authority to deal with problem banks.

${ }^{17}$ The financial system includes four commercial banks, one small state-owned development bank, and the NBFI sector. The latter comprises 49 institutions and includes 2 nonbank credit institutions, 25 insurance companies, and 22 other institutions (building and loan societies, credit unions, cooperatives, and money transfer agencies).
} 
account the action plan recommended by the FSAP exercise on compliance of the offshore banking sector with the Basel Core Principles, as well as the CFATF review of AML/CFT. ${ }^{18}$

\section{Fiscal Policy}

\section{The authorities reiterated their commitment to pursue a prudent fiscal} policy. They emphasized their intention to contain current expenditure so as to achieve a current surplus of at least 3 percent of GDP in 2004. The mission's preliminary projections indicated that absent the one-off factors contributing to revenue growth in 2003, the current surplus could reach close to 33/4 percent of GDP and the overall deficit of the central government could increase slightly to 2 percent of GDP in 2004. However, the staff's preliminary estimates suggested that an increase in current surplus of 1 percentage point of GDP to around 43/4 percent (and a corresponding decline in the overall deficit) would be consistent with the achievement of the ECCB's guideline for the debt-to-GDP ratio by 2008.

22. The authorities have decided to grant wage increases to civil service employees totaling 7 percent over 2004-05. ${ }^{19}$ While an increase in public sector wages and salaries was expected following two years of wage freeze, the mission expressed concern about the potential signaling effect of the government decision (announced during the mission's stay), as it could lead to high wage increases in the private sector and dampen growth prospects. The authorities indicated that, in general, public sector wage awards follow (and are less than) those in the private sector and not the other way around. Furthermore, they stated that the adjustment was needed in order to preserve the morale of the civil service and retain qualified employees.

23. Given the continued weakness in private sector activity, the authorities viewed the public sector investment program (PSIP) as key to stimulating economic growth in the near term and providing the basis for private sector-led growth in the medium term. They agreed with the mission that it is important that the PSIP focus only on projects that are aimed at enhancing the economy's growth potential and are largely financed on concessional terms to ensure debt sustainability. The authorities noted that debt levels remain amongst the lowest in the ECCU and that, given the concessional nature of much of the debt stock, the economy could sustain a somewhat higher debt-toGDP ratio.

18 The ECCU Financial System Stability Assessment (the staff report on which is being prepared and will be issued shortly) found that the offshore banking sector was noncompliant with nine of the 30 Basel Core Principles.

19 The wage increases are phased, 4 percent in 2004 and 3 percent in 2005. Public sector wage negotiations in the past have normally resulted in three-year contracts. 
24. The authorities agreed that a key element in ensuring medium-term fiscal sustainability is the continuous control over current spending, in particular the wage bill. In this context, the mission stressed that given the large size of the wage bill, a prudent wage and employment policy as well as civil service reform to increase its efficiency need to play a central role in rationalizing expenditure. The authorities noted that the government was committed to civil service reform and, in this vein, has established a Public Sector Reform Unit, which will focus on four areas: (i) establishment of a performance management and development system; (ii) reclassification of the public service; (iii) revision of the regulatory instruments; and (iv) improvement of customer service. Work is proceeding on most of these areas, including the reclassification exercise which is on target for a phased implementation starting in about two years. The authorities are also looking forward to the upcoming public expenditure review with the World Bank which could help in streamlining and improving the efficiency of spending.

25. The authorities have embarked on a tax reform aimed at simplifying the tax system and broadening the tax base. Major steps include the introduction of a valueadded tax (VAT), a review of the property tax, and the elimination of ad hoc tax exemptions - consistent with the preliminary report of the OECS Tax Reform and Administration Commission. In 2004, the authorities plan to establish a VAT implementation unit within the ministry of finance, with a view to introducing the VAT in 2006. To this end, they have requested technical assistance from the Fund/CARTAC. The government also intends to modernize the property tax over the medium term by replacing the current system based on ascribed rental value with one based on marketvalue assessments.

26. The authorities are committed to building efficient and accountable public institutions, including the public enterprises. In this connection, the mission noted that notwithstanding some progress toward restructuring public enterprises, additional steps are needed to strengthen their financial position and enhance efficiency. In particular, the staff recommended: (i) establishing explicit financial goals and performance indicators for the public enterprises, particularly for the electricity and water companies, with full management accountability; and (ii) advancing preparations for commercial public enterprises (such as the Marketing Corporation and the electricity company-VINLEC) to be listed on the Eastern Caribbean Stock Exchange, as a key step towards divestiture. The authorities agreed to strengthen the quarterly financial performance reviews and expedite the implementation of strategic corporate plans that have been established for public enterprises. 


\section{Competitiveness and Growth}

27. The authorities agreed that in the context of the fixed exchange rate regime, competitiveness depends crucially on continued fiscal discipline, wage moderation and labor market flexibility, and increased factor productivity. The mission noted that even though the Eastern Caribbean dollar had depreciated by about 13 percent in real effective terms over the last two years (October 2001-October 2003), in line with the depreciation of the U.S. dollar vis-à-vis other major currencies, a number of indicators (e.g., slow growth, weak exports, and high unemployment) suggest that competitiveness is weak, at least in some sectors. Recent increases in private sector wages, including the minimum wages, have likely weakened competitiveness further. Nevertheless, the performance of the St. Vincent and the Grenadines' tourism sector has been better than the ECCU average in recent years.

\section{The authorities stressed that} further restructuring of the banana sector, reduction of telecommunication costs, and improvements in labor market flexibility, will enhance the growth prospects. Given that the medium-term prospects for the banana sector remain uncertain, the authorities have appropriately stepped up their agricultural diversification and agro-processing programs. The government has facilitated growth in the telecommunication sector as it liberalized the market by granting licenses for fixed lines, private networks, and internet broadband. As for the labor market, the authorities have made welcome efforts to improve the supply of skilled labor (for example, through expanded vocational training programs). The mission, however, noted that the recent increase in guaranteed severance payments (with a corresponding increase in minimum service time requirement) is counterproductive as it serves to limit labor market flexibility.

29. Notwithstanding their efforts, the authorities agreed that reforms in several areas are needed to enhance the economy's growth potential. Key hindrances to growth include weak institutional capacity, labor market rigidities, small size of the economy, import licenses and price controls, and high cost of doing business. The 
authorities consider the lack of institutional capacity as the main impediment to growth and are taking steps to strengthen public institutions. The staff noted that the constraints imposed by the small size of the economy can be eased by accelerating efforts to enhance access to global markets and deepen regional integration through both CARICOM and the FTAA. In this connection, the mission encouraged the authorities to proceed with further trade liberalization, including by abolishing import licenses and converting existing quota restrictions into tariffs. The authorities indicated that they are committed to regional economic integration and are actively pursuing the early and full implementation of the Caribbean Single Market and Economy (CSME). They also noted that most import licenses as well as price controls are not enforced, but a lack of institutional capacity has prevented the repealing of related regulations. The mission welcomed the government's efforts to promote foreign investment and noted that the cost of doing business could be reduced by improving efficiency in public enterprises including the utilities.

\section{E. Other Issues}

30. The government has made substantial efforts to generate a broad consensus for its economic program through its dialogue with civil society. The staff noted that such efforts, including a regular program of town hall meetings, would help strengthen the public's understanding of the economic challenges currently being faced and the government's strategy for their resolution.

31. The statistical base has improved in recent years, but remaining weaknesses hamper the quality of economic analysis. Specific areas of weakness include labor market data, national accounts, and balance of payments statistics. The mission encouraged the authorities to strengthen the central statistical office, including by taking advantage of technical assistance from CARTAC.

\section{F. Medium-Term Outlook and Debt Sustainability Analysis}

\section{The principal medium-term}

challenges are to reinvigorate private sector growth and maintain fiscal discipline. The development of a dynamic private sector in the medium-term could be facilitated by the abovementioned reforms in a number of key areas (public finances, financial sector, and labor market). The staff developed two medium term scenarios, a baseline scenario which assumes the continuation of current trends and policies, and

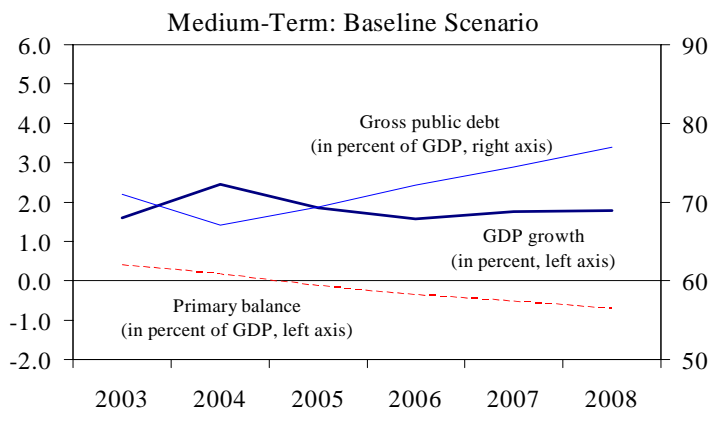
an alternative scenario which assumes accelerated reforms and an increasing role for the private sector. In the baseline scenario, growth would level off at less than 2 percent a year during 2005-08, and, in this context, the public sector primary surplus (projected at about $1 / 4$ percent of GDP in 2004) would turn into a deficit of $3 / 4$ percent of GDP and public debt would rise to 77 percent of GDP by 2008 (Table 10). In the alternative scenario, annual real GDP growth would rise to $2-$ 
$2 \frac{1}{2}$ percent, the primary surplus would increase to $43 / 4$ percent of GDP, and the debt-to-GDP ratio would decline to about 60 percent of GDP by 2008 (in line with the ECCB's benchmark).

\section{The staff prepared a debt} sustainability analysis based on the above scenarios (Tables 11 and 12). The analysis underscores the vulnerabilities stemming from

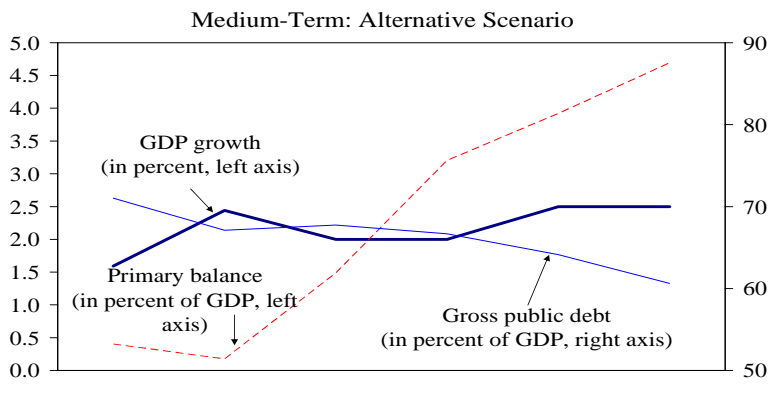

Source: Fund staff estimates and projections. high debt in St. Vincent and Grenadines' shock-prone environment. Stress tests point to the potentially negative impact of various shocks of an average magnitude. They indicate that exogenous shocks could potentially raise the debt level above 80 percent and that additional fiscal effort beyond the alternative scenario would be needed.

\section{STAFF APPRAISAL}

34. St. Vincent and the Grenadines faces difficult policy challenges. The modest growth of the last two years has been supported by expansionary fiscal policies, while private sector activity has been weak. Recent increases in private sector wages, including the minimum wage, at a time when the economy is adjusting to permanent negative shocks, have likely weakened competitiveness. Unemployment remains high, raising concerns about deepening poverty.

35. The authorities have been successful in maintaining macroeconomic stability in a very difficult regional and global environment. While pursuing a countercyclical fiscal stance, the fiscal stimulus has come through higher investment offset in part by an increase in current revenue. The latter reflected one-off factors as well as welcome improvements in broadening the tax base, removing tax concessions, and strengthening tax administration. Similarly, the authorities' efforts at containing current expenditure, partly reflecting the 2002-03 wage freeze as well as tight control over other goods and services, are commendable.

36. While public sector debt remains amongst the lowest in the ECCU and is mostly on concessional terms, the authorities need to pursue cautious fiscal policies to reduce vulnerabilities. Fiscal policy needs to aim at containing current expenditure - in particular the wage bill-and strengthening government revenue by implementing the envisaged tax reform measures. It would be important that public sector investment focus on key priority projects aimed at enhancing the economy's growth potential and largely financed on concessional terms. At the same time, the authorities need to take additional steps to strengthen the financial position of the public enterprises and improve their efficiency.

37. The key challenge in the medium term is to reinvigorate private sector growth, while preserving macroeconomic stability and reducing public debt. The current strategy of promoting growth through expansionary fiscal policies can provide a temporary boost to the economy, but given the already large public debt outstanding, the 
risks to debt sustainability should not be underestimated. The development of a dynamic private sector could be facilitated by addressing constraints to growth and competition in the economy - such as weak institutional capacity and labor market inflexibility-while preserving macroeconomic stability and the currency board arrangement.

38. Developing and implementing a clear strategy for restructuring the stateowned National Commercial Bank are urgently needed to remove this key vulnerability of the financial system. The steps being taken by the authorities in this area are in the right direction, and should be reinforced by the adoption of the measures proposed by the FSAP. Strengthening the regulation and effectiveness of supervision of nonbank financial institutions would also reduce risks, given the rapid increase in their level of activity in recent years. As for the offshore sector, the implementation of the action plan recommended by the FSAP is essential to ensure the full compliance of this sector with Basel Core Principles.

39. The stress faced by some ECCU countries suggests that the authorities need to develop a plan to deal with potential contagion without delay. While the stronger starting point of St. Vincent and the Grenadines provides some room for maneuver in the event that problems emerge, complacency should be avoided. The identification of fiscal contingency measures to reduce financing needs should be an important element of such a plan.

40. The envisaged recovery in economic activity should facilitate the maintenance of the current high levels of social services, human capital, and a reduction in poverty. Thus, the full implementation of the government's poverty reduction strategy and stemming the spread of HIV/AIDS needs to be given the highest priority.

41. The government's efforts to generate a broad consensus for its economic program through its dialogue with civil society are commendable and should continue. Such steps can only strengthen the public's understanding of the economic challenges currently being faced and the government's strategy to address them.

42. Weaknesses in the statistical base need to be addressed. The staff encourages the authorities to strengthen the central statistical office, including by taking advantage of the available technical assistance.

43. It is proposed that the next Article IV consultation with the St. Vincent and the Grenadines take place on the standard 12-month cycle. 


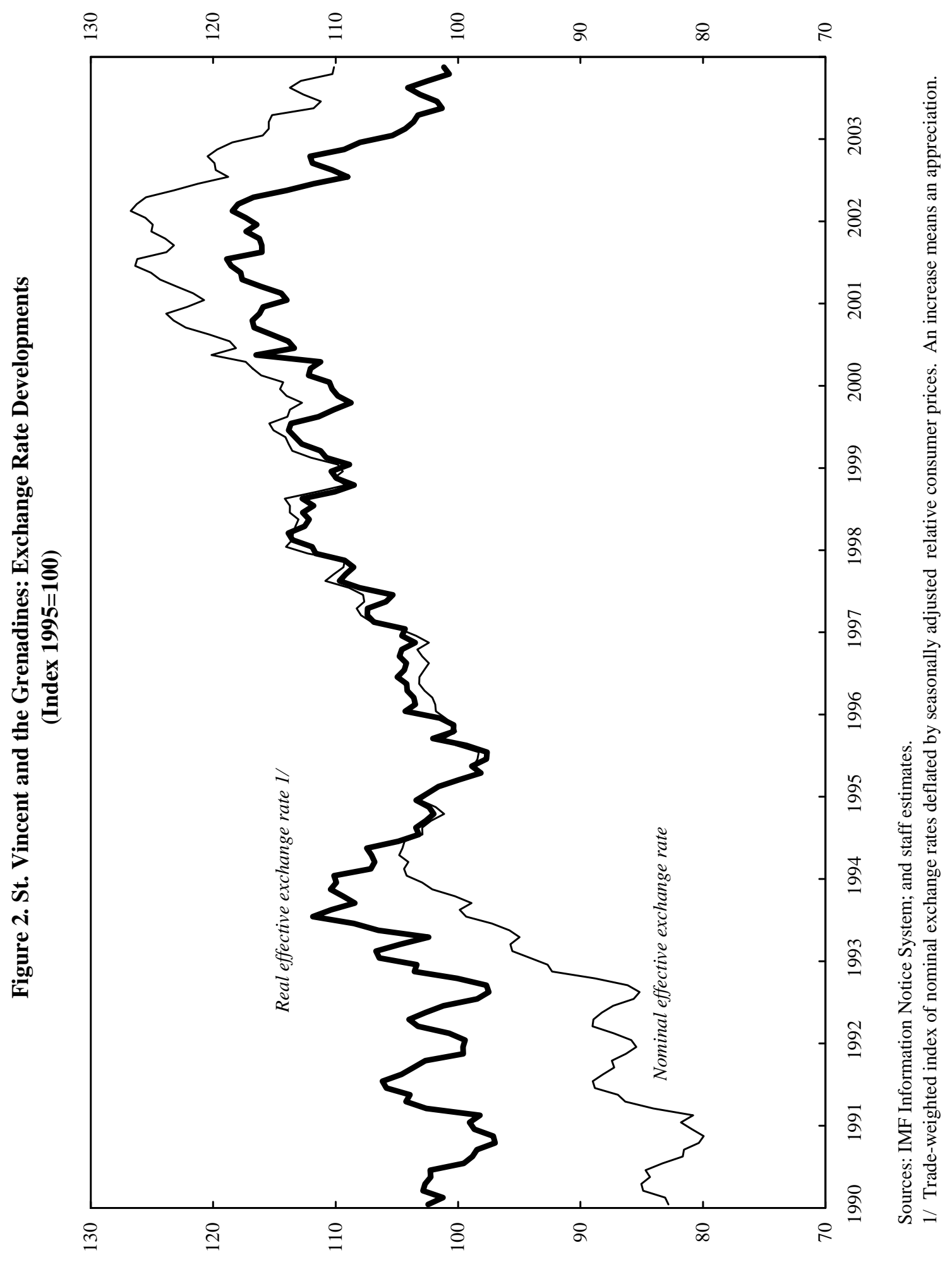




\section{Box 1. Poverty Reduction Strategy}

The most recent source of statistical data on the incidence of poverty in St. Vincent and the Grenadines is "the Poverty Assessment Report" prepared by a group of consultants in 1996. The report states that $371 / 2$ percent of the population (30.6 percent of households) are poor, of which 25.7 percent of the population (20.4 percent of households) are indigent. A study prepared in 2001 on "the Socio-Economic Impact of Restructuring the Banana Industry" indicates a worsening of the poverty situation as a result of severe shocks to the economy since 1995.

The process to develop a poverty reduction strategy began in September 2001. The government assigned the responsibility for the development of a Poverty Reduction Framework to the National Economic and Social Development Council (NESDC), which comprises representatives from the government ministries, ECCB and other financial institutions, private sector, and civil society groups. A Poverty Reduction Task Force was established by the NESDC to develop the Poverty Reduction Strategy. The final revision of the Interim Poverty Reduction Strategy Paper (IPRSP) was completed in June 2003. The IPRSP serves as a blueprint for achieving the Millennium Development Goals: (i) eradicating extreme poverty and hunger by halving the level of poverty (the proportion of people living on less than a dollar a day and those who suffer from hunger) by 2015; (ii) achieving universal primary education; (iii) promoting gender equality and empowering women; (iv) reducing child mortality; (v) improving maternal health; (vi) combating HIV/AIDS, malaria and other diseases; (vii) ensuring environmental sustainability; and (viii) developing a global partnership for development.

The strategy for poverty reduction adopted by the government follows a multi-faceted approach, which includes: (i) a job creation program (including the Youth Empowerment Service to address youth unemployment); (ii) a low income housing project; (iii) an enhanced safety net for the poor through public assistance; and (iv) the promotion of a micro-enterprise sector. 


\section{Box 2. Labor Market and Minimum Wages}

The labor force: About 37,000 persons are employed (of which more than 5,000 in the public sector); about 6,000 are union members; according to the 2001 census the unemployment rate was 20.8 percent.

\begin{tabular}{|c|c|c|c|c|c|c|c|c|c|c|c|c|}
\hline & & & & & $\begin{array}{l}\text { Vincent and the } \\
\text { (in perc }\end{array}$ & $\begin{array}{l}\text { Grenadines: } \mathrm{Em} \\
\text { ent of total em }\end{array}$ & $\begin{array}{l}\text { ployment by Sect } \\
\text { ployment) }\end{array}$ & or $1 /$ & & & & \\
\hline Agriculture & $\begin{array}{l}\text { Public } \\
\text { admin. }\end{array}$ & $\begin{array}{l}\text { Distri. } \\
\text { Trade }\end{array}$ & $\begin{array}{c}\text { Hotels \& } \\
\text { restaurants }\end{array}$ & Construction & $\begin{array}{c}\text { Social \& } \\
\text { personal serv. }\end{array}$ & Manufacture & $\begin{array}{c}\text { Transport \& } \\
\text { communication }\end{array}$ & $\begin{array}{l}\text { Real estate \& } \\
\text { business serv. }\end{array}$ & $\begin{array}{c}\text { Financial } \\
\text { intermediation }\end{array}$ & $\begin{array}{c}\text { Education \& } \\
\text { health }\end{array}$ & Utilities & Oth. \\
\hline 23 & 15 & 10 & 6 & 6 & 6 & 5 & 4 & 3 & 3 & 3 & 2 & 14 \\
\hline
\end{tabular}

Wage developments: Wage increases in the central government have been generally in line with those in the public enterprises, except for 2002 and 2003, when the freeze of the central government wages resulted in a cumulative base-wage difference of about 7 percent. Limited private sector wage data indicate a small wage premium over the public sector as well as additional performance-based merit increases of up to 3 percent a year in some private firms and public enterprises.

St. Vincent and the Grenadines: Wages

(Annual percentage change)

\begin{tabular}{|c|c|c|c|c|c|}
\hline & 1999 & 2000 & 2001 & 2002 & 2003 \\
\hline Central government $1 /$ & 5.0 & 3.5 & 3.5 & 0 & 0 \\
\hline Public enterprises $2 /$ & 3.4 & 3.5 & 3.5 & 3.0 & 3.8 \\
\hline \multicolumn{6}{|l|}{ Private sector } \\
\hline Geest, and Cable and Wireless & 4.0 & 3.0 & 4.0 & 4.0 & 4.0 \\
\hline
\end{tabular}

Minimum wages: After 14 years, minimum wages were increased in May 2003. A lack of data precludes any meaningful assessment of the effects the new minimum wages have had on other wages and employment. Discussions with the representatives from the public and private sectors suggested a mixed picture. Some businesses reportedly have been paying wages above the new minimum levels prior to May 2003, while for a number of other businesses (including banana farmers) the new minimum wages have created difficulties, including a reduction in the number of employees or work hours.

St. Vincent and the Grenadines: Minimum Wages

(In Eastern Caribbean dollars)

\begin{tabular}{lrr}
\hline & 1989 & 2003 \\
\hline Agriculture (per day) & 18 & 25 \\
Manufacturing (skilled per day) & 20 & 30 \\
Manufacturing (unskilled per day) & 18 & 25 \\
Domestic (living in per month) & 125 & 300 \\
Domestic (not living in per month) & 200 & 350 \\
Shop assistant (per week) & 72 & 125 \\
Shop assistant (per month) & 400 & 500 \\
Hotel workers (per month) & n.a. & 700 \\
Security workers (per month) & n.a. & 600 \\
Workers in offices of professionals (per month) & n.a. & 600 \\
\hline
\end{tabular}

Sources: Ministry of Finance and Planning and Minimum Wage Orders 2003. 


\section{Box 3. Financial Sector Vulnerabilities}

Banking system: The risks in the banking system are concentrated in the state-owned National Commercial Bank (NCB), which has a high nonperforming loans (NPL) ratio and is heavily exposed to the public sector. Aggregate NPL ratio is around 13 percent, and despite the macroeconomic difficulties, has not deteriorated significantly in recent years. Foreign currency deposits as a share of total deposits are very small and have steadily declined since early 2001. Foreign currency and interest rate risks are limited. Cross border exposures to the other ECCU countries are low, suggesting that contagion risks may come through overall confidence effects rather than direct financial linkages.

Exposure to the public sector: The banking system's aggregate exposure to the public sector is about 10 percent of the total banking system assets. Net claims on the public sector are much smaller, reflecting the large National Insurance System (NIS) and government deposits, of which about 40 percent may not be freely available. Banks' investments in home country treasury bills account for a small portion of their gross exposure to government, although individual banks' exposures to the three-month treasury bills can vary considerably, depending on the outcome of the treasury bill auctions in the Regional Government Securities Market (RGSM). Banks' net exposures to public enterprises are very small, and banks' indirect exposures to the government through the use of government securities (treasury bills and bonds) as collateral are limited.

Banking System's Credit to the Public Sector (as of September 2003)

\begin{tabular}{|c|c|c|c|c|}
\hline & \multicolumn{2}{|c|}{ Foreign Banks } & \multicolumn{2}{|c|}{ Local Banks 1/ } \\
\hline & $\begin{array}{r}\text { (millions } \\
\text { of EC\$) } \\
\end{array}$ & $\begin{array}{r}\text { (percent of } \\
\text { total assets) }\end{array}$ & $\begin{array}{r}\text { (millions } \\
\text { of EC\$) } \\
\end{array}$ & $\begin{array}{r}\text { (percent of } \\
\text { total assets) } \\
\end{array}$ \\
\hline Gross credit to the public sector & 38.3 & 7.0 & 124.9 & 15.8 \\
\hline Gross credit to central government & 38.0 & 6.9 & 98.6 & 12.5 \\
\hline Gross credit to nonfinancial public enterprises & 0.3 & 0.1 & 26.3 & 3.3 \\
\hline Net credit to the public sector & 3.6 & 0.7 & -105.3 & -13.3 \\
\hline Net credit to central government & 13.6 & 2.5 & 9.0 & 1.1 \\
\hline Net credit to NIS & -9.1 & -1.7 & -131.6 & -16.6 \\
\hline Net credit to nonfinancial public enterprises & -0.9 & -0.2 & 17.3 & 2.2 \\
\hline Total capital of the banking system & n.a. & n.a. & 79.1 & 10.0 \\
\hline Total assets of the banking system & 548.8 & 41.0 & 790.3 & 59.0 \\
\hline
\end{tabular}

Sources: ECCB; and Fund staff calculations.

1/ Include the NCB and the locally incorporated branch of the Royal Bank of Trinidad and Tobago.

Prudential indicators: Prudential indicators provide mixed signals about the strengths of the banking system, but point to significant weakness of the NCB which holds about a third of the banking system assets. However, indicators of asset quality need to be treated with caution for two reasons. The indicators are based on bank-reported numbers, and the quality of reported capital is uncertain, given the possible under-provisioning of NPLs and the zero risk-weights applied to public sector debt in arrears. The robustness among foreign banks may also vary, depending on the quality of the supervision in the parent company country.

Other risks: Adverse shocks to the real economy may have negative effects on banks' balance sheets as they may affect their loan portfolios. The hurricanes that affected the region in the past have reportedly led to increases in the NPLs of the agricultural and tourism sectors. Loans to the household sector account for about one-half of the total bank loans; most of these loans are mortgages and for consumer durables. Although historically default rates on mortgages have been the lowest among private sector loans, banks' exposures to the household sector could be potentially destabilizing, as the semi-annual adjustment of interest rates on mortgages could reduce the borrowers' ability to service the loans should interest rates increase. This default risk, combined with the possible misvaluation of underlying property, could lead to substantial losses for the banks.

Nonbank financial institutions (NBFI): Some NBFIs are experiencing financial difficulties, but the sector is not likely to pose serious risk to the stability of the financial system because the problematic NBFIs are small in size and their liquidity linkages to the banks are limited. However, the reputation risk associated with the failure in one credit union might spread to others on the same island, affecting foremost the rural areas where members are least capable of absorbing losses. 
Table 1. St. Vincent and the Grenadines: Selected Economic Indicators

\begin{tabular}{|c|c|c|c|c|c|c|}
\hline & 1999 & 2000 & 2001 & $\begin{array}{l}\text { Prel. } \\
2002\end{array}$ & $\begin{array}{r}\text { Est. } \\
2003\end{array}$ & $\begin{array}{l}\text { Proj. } \\
2004\end{array}$ \\
\hline \multicolumn{7}{|c|}{ (Annual percentage changes, unless otherwise specified) } \\
\hline \multicolumn{7}{|l|}{ Output and prices } \\
\hline Real GDP (factor cost) & 3.6 & 2.0 & -0.1 & 1.4 & 1.6 & 2.4 \\
\hline Nominal GDP (market prices) & 4.1 & 1.5 & 3.3 & 4.3 & 2.9 & 3.9 \\
\hline Consumer prices, end of period & -1.8 & 1.4 & -0.6 & 0.4 & 1.5 & 1.8 \\
\hline Real effective exchange rate $1 /$ & -0.1 & 5.1 & 0.5 & -7.2 & -13.4 & \\
\hline External terms of trade & -9.4 & -3.3 & 2.9 & 2.1 & -5.2 & -0.8 \\
\hline \multicolumn{7}{|l|}{ Banking system } \\
\hline Net foreign assets $2 /$ & 7.0 & 11.2 & -4.1 & 2.9 & 6.2 & 5.5 \\
\hline Net domestic assets $2 /$ & 5.5 & -1.7 & 7.2 & 5.4 & -3.3 & -1.6 \\
\hline \multicolumn{7}{|l|}{ Of which } \\
\hline Net credit to the public sector $2 /$ & 2.1 & 1.9 & 0.3 & 4.8 & -6.4 & -1.5 \\
\hline Credit to private sector $2 /$ & 11.5 & 8.0 & 2.1 & 4.3 & 1.3 & 1.3 \\
\hline Broad money $2 /$ & 12.5 & 9.5 & 3.0 & 8.3 & 2.9 & 3.9 \\
\hline Average deposit interest rate (in percent per annum) & 4.6 & 4.6 & 4.5 & 4.5 & $\ldots$ & $\ldots$ \\
\hline Average lending interest rate (in percent per annum) & 11.6 & 11.5 & 11.9 & 11.5 & $\ldots$ & $\ldots$ \\
\hline Nonperforming loans to total loans $3 /$ & 13.1 & 10.9 & 13.0 & 11.3 & 13.1 & $\ldots$ \\
\hline \multicolumn{7}{|c|}{ (In percent of GDP, unless otherwise specified) } \\
\hline \multicolumn{7}{|l|}{ Nonfinancial public sector } \\
\hline \multicolumn{7}{|l|}{ Central government } \\
\hline Total revenue and grants & 30.2 & 29.4 & 30.6 & 32.1 & 32.6 & 31.8 \\
\hline Total expenditure & 33.6 & 31.4 & 32.7 & 34.4 & 33.9 & 33.8 \\
\hline \multicolumn{7}{|l|}{ Of which } \\
\hline Wages and salaries & 14.3 & 14.1 & 14.2 & 14.6 & 14.1 & 14.4 \\
\hline Overall balance (cash basis) 4/ & -2.2 & -2.0 & -2.1 & -4.2 & -1.3 & -2.0 \\
\hline \multicolumn{7}{|l|}{ Of which } \\
\hline Savings & 2.1 & 1.6 & 1.0 & 2.6 & 4.1 & 3.6 \\
\hline Primary balance & 0.4 & 0.8 & 0.5 & -1.6 & 1.3 & 0.0 \\
\hline Gross public sector debt $5 / 6 / 7 /$ & 65.8 & 67.5 & 69.2 & 71.5 & 71.0 & 67.1 \\
\hline Public sector overall balance 5/ & -0.8 & -1.4 & -1.8 & -4.1 & -2.6 & -2.4 \\
\hline Public sector primary balance 5/ & 2.3 & 1.7 & 1.4 & -1.0 & 0.4 & 0.2 \\
\hline Public sector investment $5 /$ & 14.7 & 7.1 & 8.6 & 10.1 & 10.5 & 10.0 \\
\hline \multicolumn{7}{|l|}{ External sector } \\
\hline External current account & -22.2 & -8.1 & -10.9 & -9.6 & -16.1 & -13.3 \\
\hline \multicolumn{7}{|l|}{ Of which } \\
\hline Exports of goods and services & 53.1 & 53.1 & 50.2 & 49.2 & 47.3 & 46.8 \\
\hline Imports of goods and services & 73.7 & 61.3 & 61.1 & 60.3 & 65.0 & 61.9 \\
\hline Public sector external debt (end of period) 7/ & 48.5 & 47.8 & 49.1 & 47.1 & 50.5 & 45.0 \\
\hline \multicolumn{7}{|l|}{ External public debt service } \\
\hline In percent of exports of goods and services & 6.5 & 5.7 & 6.7 & 6.5 & 7.2 & 7.3 \\
\hline In percent of central government revenue before grants & 11.9 & 10.7 & 11.8 & 10.3 & 10.8 & 11.1 \\
\hline \multicolumn{7}{|l|}{ Memorandum items: } \\
\hline Average interest rate on the domestic public debt & 8.5 & 8.8 & 7.7 & 8.2 & 7.8 & 7.8 \\
\hline Average interest rate on the external public debt & & 2.8 & 3.2 & 2.7 & 2.5 & 1.7 \\
\hline Nominal GDP at market prices (in millions of U.S. dollars) & 330.4 & 335.4 & 346.4 & 361.1 & 371.5 & 386.0 \\
\hline
\end{tabular}

Sources: Eastern Caribbean Central Bank, Ministry of Finance and Planning; Banana Growers' Association, and Fund staff estimates and projections.

$1 /$ In 2003, refers to twelve month period ending October.

2/ Annual changes relative to the stock of broad money at the beginning of the period.

$3 /$ The figure for 2003 is for end-June.

4/ Includes the difference between the overall balance as measured from above the line and from below the line (i.e. financing), which may include float and unidentified discrepancies.

5/ The consolidated public sector includes the central government, the National Insurance Scheme (NIS), Kingstown Board, and 10 nonfinancial public enterprises.

6/ Net of intra-public sector debt (mainly central government debt to the NIS).

7/ Ottley Hall financiers indicated in principle to write off EC\$49.6 million (5 percent of GDP) in 2004. 
Table 2. St. Vincent and the Grenadines: Summary of Consolidated Public Sector Operations

\begin{tabular}{|c|c|c|c|c|c|c|}
\hline & 1999 & 2000 & 2001 & $\begin{array}{l}\text { Prel. } \\
2002\end{array}$ & $\begin{array}{r}\text { Est. } \\
2003\end{array}$ & $\begin{array}{l}\text { Proj. } \\
2004\end{array}$ \\
\hline \multicolumn{7}{|c|}{ (In millions of Eastern Caribbean dollars) } \\
\hline Total revenue and grants & 297 & 298 & 319 & 342 & 354 & 362 \\
\hline Current revenue & 279 & 287 & 301 & 331 & 343 & 350 \\
\hline Central government current revenue & 252 & 256 & 268 & 302 & 316 & 320 \\
\hline Operating balances of other public entities $1 /$ & 27 & 32 & 33 & 29 & 26 & 30 \\
\hline Capital revenue (land sales only) & 5 & 1 & 1 & 1 & 1 & 1 \\
\hline Grants & 13 & 10 & 17 & 11 & 10 & 11 \\
\hline Total expenditure & 365 & 305 & 340 & 375 & 380 & 387 \\
\hline Current expenditure & 234 & 241 & 259 & 276 & 275 & 282 \\
\hline Capital 2/ & 131 & 64 & 81 & 99 & 105 & 105 \\
\hline Central Government & 64 & 35 & 47 & 63 & 70 & 70 \\
\hline National Insurance Scheme & 0 & 0 & 14 & 6 & 0 & 6 \\
\hline Rest of the public sector & 68 & 29 & 20 & 30 & 34 & 28 \\
\hline Overall balance (above the line) & -69 & -7 & -20 & -33 & -27 & -25 \\
\hline Other $3 /$ & -62 & 6 & -4 & 7 & 0 & 0 \\
\hline Overall balance (cash basis) & -7 & -13 & -17 & -40 & -27 & -25 \\
\hline \multicolumn{7}{|l|}{ Of which } \\
\hline Savings & 45 & 47 & 42 & 55 & 68 & 67 \\
\hline Primary balance & 21 & 15 & 13 & -9 & 4 & 2 \\
\hline Identified financing & 7 & 13 & 17 & 40 & 27 & 25 \\
\hline Net external financing & 5 & 7 & 31 & 3 & 47 & 13 \\
\hline Disbursements & 21 & 23 & 48 & 22 & 69 & 40 \\
\hline Amortization & 16 & 16 & 17 & 19 & 22 & 27 \\
\hline Change in government foreign assets & 2 & 2 & 0 & 0 & 2 & 2 \\
\hline Net domestic financing & 0 & 0 & -26 & 36 & -24 & 11 \\
\hline \multicolumn{7}{|l|}{ Of which } \\
\hline Banking system & 11 & 12 & 2 & 31 & -45 & -11 \\
\hline Exceptional financing (Ottley Hall moratorium) & 0 & 0 & 1 & 1 & 1 & 0 \\
\hline Sale of assets & 1 & 4 & 12 & 1 & 1 & 0 \\
\hline \multicolumn{7}{|c|}{ (In percent of GDP) } \\
\hline Total revenue and grants & 33.2 & 33.0 & 34.1 & 35.1 & 35.3 & 34.7 \\
\hline Current revenue & 31.3 & 31.7 & 32.2 & 33.9 & 34.2 & 33.6 \\
\hline Total expenditure & 40.9 & 33.7 & 36.3 & 38.5 & 37.9 & 37.1 \\
\hline Current expenditure & 26.2 & 26.6 & 27.7 & 28.3 & 27.4 & 27.1 \\
\hline Capital & 14.7 & 7.1 & 8.6 & 10.1 & 10.5 & 10.0 \\
\hline Overall balance (above the line) & -7.7 & -0.7 & -2.2 & -3.4 & -2.6 & -2.4 \\
\hline Overall balance (cash basis) & -0.8 & -1.4 & -1.8 & -4.1 & -2.6 & -2.4 \\
\hline \multicolumn{7}{|l|}{ Of which } \\
\hline Savings & 5.1 & 5.1 & 4.5 & 5.6 & 6.7 & 6.5 \\
\hline Primary balance & 2.3 & 1.7 & 1.4 & -1.0 & 0.4 & 0.2 \\
\hline Net external financing & 0.5 & 0.8 & 3.3 & 0.3 & 4.7 & 1.2 \\
\hline Net domestic financing & 0.0 & 0.0 & -2.8 & 3.7 & -2.4 & 1.0 \\
\hline
\end{tabular}

Sources: Ministry of Finance and Planning; and Fund staff estimates and projections.

1/ Operating balances (current revenue less current expenditure) for the National Insurance Scheme, Kingstown Board, and 10 nonfinancial public enterprises.

2/ The figures for 2003-04 represent Fund staff projections based on historical implementation rates.

3/ The difference between the overall balance as measured from above the line and from below the line (i.e. financing), which may include float and unidentified discrepancies. 
Table 3. St. Vincent and the Grenadines: Summary of Central Government Operations

\begin{tabular}{|c|c|c|c|c|c|c|}
\hline & 1999 & 2000 & 2001 & $\begin{array}{l}\text { Prel. } \\
2002 \\
\end{array}$ & $\begin{array}{r}\text { Est. } \\
2003 \\
\end{array}$ & $\begin{array}{l}\text { Proj. } \\
2004 \\
\end{array}$ \\
\hline \multicolumn{7}{|c|}{ (In millions of Eastern Caribbean dollars) } \\
\hline Total revenue and grants & 270 & 267 & 286 & 313 & 327 & 332 \\
\hline Current revenue & 252 & 256 & 268 & 302 & 316 & 320 \\
\hline $\operatorname{Tax}$ & 215 & 216 & 231 & 260 & 270 & 270 \\
\hline Nontrade tax & 105 & 114 & 119 & 133 & 132 & 137 \\
\hline International trade & 111 & 102 & 112 & 127 & 139 & 133 \\
\hline Nontax & 37 & 39 & 38 & 42 & 46 & 50 \\
\hline Capital revenue (land sales only) & 5 & 1 & 1 & 1 & 1 & 1 \\
\hline Grants & 13 & 10 & 17 & 11 & 10 & 11 \\
\hline Total expenditure and net lending & 300 & 285 & 306 & 336 & 340 & 352 \\
\hline Current & 234 & 241 & 259 & 276 & 275 & 282 \\
\hline Wages and salaries & 128 & 127 & 132 & 143 & 142 & 150 \\
\hline Interest & 23 & 26 & 25 & 26 & 25 & 21 \\
\hline Of which: foreign interest & 14 & 13 & 13 & 11 & 12 & 8 \\
\hline Goods and services & 51 & 53 & 53 & 64 & 64 & 66 \\
\hline Transfers & 32 & 35 & 49 & 43 & 44 & 45 \\
\hline Capital expenditure 1/ & 64 & 35 & 47 & 63 & 70 & 70 \\
\hline Net lending & 3 & 9 & 0 & -4 & -5 & 0 \\
\hline Current balance (before grants) & 18 & 15 & 9 & 26 & 41 & 38 \\
\hline Overall balance (above the line) & -30 & -18 & -19 & -22 & -13 & -20 \\
\hline Other $2 /$ & -11 & 1 & 0 & 19 & 0 & 0 \\
\hline Overall balance (cash basis) & -19 & -19 & -20 & -41 & -13 & -20 \\
\hline Of which: primary balance & 4 & 7 & 5 & -15 & 13 & 0 \\
\hline Identified financing & 19 & 19 & 20 & 41 & 13 & 20 \\
\hline Net external financing & 6 & 10 & 33 & 3 & 52 & 15 \\
\hline Disbursements & 17 & 21 & 46 & 20 & 65 & 40 \\
\hline Amortization & 11 & 11 & 13 & 16 & 13 & 25 \\
\hline Change in government foreign assets & 2 & 2 & 0 & 0 & 2 & 2 \\
\hline Net domestic financing & 12 & 7 & -14 & 37 & -43 & 4 \\
\hline Of which: banking system & 9 & 6 & -18 & 42 & -28 & -6 \\
\hline Exceptional financing & 0 & 0 & 1 & 1 & 1 & 0 \\
\hline \multicolumn{7}{|c|}{ (In percent of GDP, unless otherwise specified) } \\
\hline Total revenue and grants & 30.2 & 29.4 & 30.6 & 32.1 & 32.6 & 31.8 \\
\hline Of which: current revenue & 28.3 & 28.2 & 28.7 & 31.0 & 31.5 & 30.7 \\
\hline Total expenditure and net lending & 33.6 & 31.4 & 32.7 & 34.4 & 33.9 & 33.8 \\
\hline Current & 26.2 & 26.6 & 27.7 & 28.3 & 27.4 & 27.1 \\
\hline Wages and salaries & 14.3 & 14.1 & 14.2 & 14.6 & 14.1 & 14.4 \\
\hline Interest & 2.6 & 2.8 & 2.6 & 2.7 & 2.5 & 2.0 \\
\hline Goods and services & 5.7 & 5.9 & 5.7 & 6.6 & 6.4 & 6.4 \\
\hline Transfers & 3.6 & 3.8 & 5.2 & 4.5 & 4.4 & 4.3 \\
\hline Capital expenditure & 7.1 & 3.9 & 5.0 & 6.5 & 7.0 & 6.7 \\
\hline Net lending & 0.3 & 0.9 & 0.0 & -0.4 & -0.5 & 0.0 \\
\hline Other & -1.2 & 0.1 & 0.0 & 1.9 & 0.0 & 0.0 \\
\hline Current balance (before grants) & 2.1 & 1.6 & 1.0 & 2.6 & 4.1 & 3.6 \\
\hline Overall balance (above the line) & -3.4 & -2.0 & -2.1 & -2.3 & -1.3 & -2.0 \\
\hline Overall balance (cash basis) & -2.2 & -2.0 & -2.1 & -4.2 & -1.3 & -2.0 \\
\hline Of which: primary balance & 0.4 & 0.8 & 0.5 & -1.6 & 1.3 & 0.0 \\
\hline Net external financing & 0.6 & 1.1 & 3.5 & 0.3 & 5.2 & 1.4 \\
\hline Net domestic financing & 1.4 & 0.8 & -1.5 & 3.8 & -4.2 & 0.3 \\
\hline \multicolumn{7}{|l|}{ Memorandum items: } \\
\hline Gross central government debt, percent of GDP 3/4/ & 59.4 & 60.8 & 62.8 & 64.1 & 62.4 & 57.1 \\
\hline GDP at market prices, EC\$ millions & 892.1 & 905.7 & 935.2 & 975.0 & $1,003.2$ & $1,042.3$ \\
\hline
\end{tabular}

Sources: Ministry of Finance and Planning; and Fund staff projections.

1/ The figures for 2003-04 represent Fund staff projections based on historical implementation rates.

2/ The difference between the overall balance as measured from above the line and from below the line (i.e., financing), which may include float and unidentified discrepancies.

3/ Net of intra-public sector debt (mainly central government debt to the NIS).

4/ The projections for 2004 assume a debt writeoff equivalent to EC\$49.6 million (5 percent of GDP), which the Ottley Hall financiers have agreed to in principle. 
Table 4. St. Vincent and the Grenadines: Public Sector Debt 1/

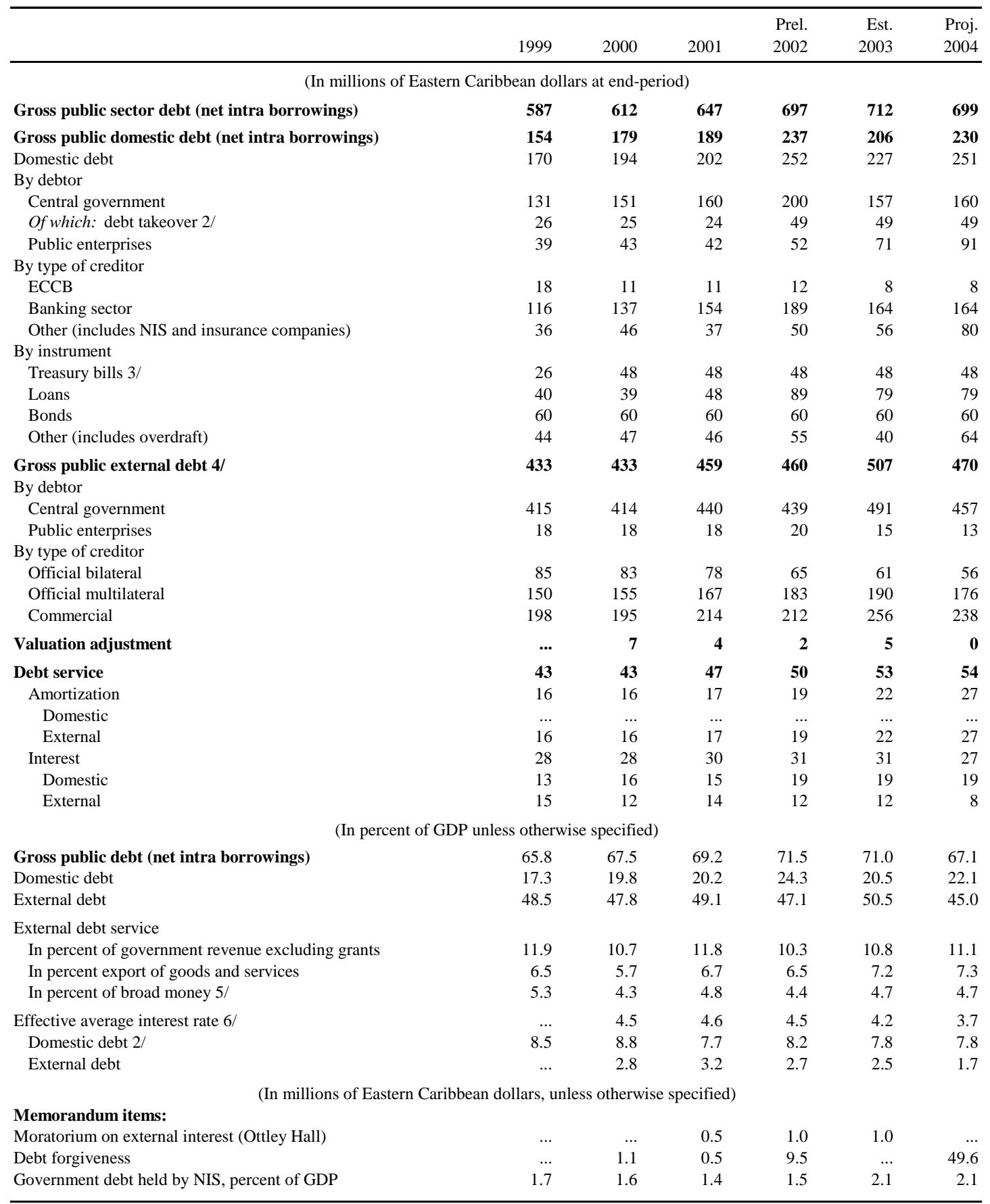

Sources: Ministry of Finance and Planning; and Fund staff estimates and projections.

1/ The consolidated public sector inlcudes the central government, the National Insurance Scheme, Kingstown Board, and 10 nonfinancial public enterprises.

2/ Government tookover public entities overdrafts whose operations were not accounted in public sector accounts namely call centers and Development bank. The overdraft was refinanced by issuing a loan.

3/ Treasury bills purchased by nonresidents on the RGSM since March 2003, are included.

4/ Includes the assumption of EC \$156 million (17.5 percent of GDP) private debt for Ottley Hall shipyard in 1999. The projections for 2004 assume a debt writeoff equivalent to EC\$49.6 million (5 percent of GDP) which the Ottley Hall financiers have agreed to in princir $5 /$ Including foreign currency deposits.

6/ Interest payment as percent of the average debt stock at beginning and end period. 
Table 5. St. Vincent and the Grenadines: Balance of Payments Summary

\begin{tabular}{|c|c|c|c|c|c|c|}
\hline & 1999 & 2000 & 2001 & $\begin{array}{l}\text { Prel. } \\
2002\end{array}$ & $\begin{array}{r}\text { Est. } \\
2003\end{array}$ & $\begin{array}{l}\text { Proj. } \\
2004\end{array}$ \\
\hline \multicolumn{7}{|c|}{ (In millions of Eastern Caribbean dollars) } \\
\hline Current account 1/ & -198 & -74 & -102 & -94 & -162 & -139 \\
\hline Trade balance & -344 & -250 & -295 & -315 & -365 & -355 \\
\hline $\begin{array}{l}\text { Exports, f.o.b. } \\
\text { Of which }\end{array}$ & \multicolumn{5}{|c|}{ Of which } & 115 \\
\hline Bananas & 55 & 49 & 37 & 43 & 32 & 44 \\
\hline Manufactured exports & 50 & 48 & 46 & 40 & 38 & 38 \\
\hline Imports, f.o.b. & 478 & 390 & 410 & 424 & 478 & 470 \\
\hline Services (net) & 160 & 175 & 193 & 207 & 188 & 198 \\
\hline Credits & 340 & 341 & 354 & 371 & 363 & 372 \\
\hline Travel & 207 & 203 & 216 & 224 & 226 & 232 \\
\hline Other nonfactor services & 133 & 137 & 138 & 147 & 137 & 141 \\
\hline Debits & 179 & 166 & 161 & 164 & 174 & 175 \\
\hline Travel & 25 & 26 & 27 & 27 & 28 & 29 \\
\hline Other nonfactor services & 155 & 139 & 135 & 136 & 146 & 146 \\
\hline Income (net) $1 /$ & -56 & -49 & -46 & -40 & -41 & -39 \\
\hline Current transfers & 42 & 51 & 45 & 55 & 56 & 57 \\
\hline Net private transfers & 39 & 43 & 47 & 56 & 57 & 59 \\
\hline Net official transfers & 2 & 7 & -1 & -1 & -1 & -1 \\
\hline Capital and financial account & 167 & 58 & 148 & 61 & 162 & 156 \\
\hline Capital 2/ & 16 & 14 & 21 & 22 & 12 & 63 \\
\hline Financial (net) & 151 & 43 & 127 & 38 & 150 & 93 \\
\hline Official capital & 5 & 7 & 31 & 3 & 47 & 13 \\
\hline Commercial banks & -26 & -31 & 43 & -41 & -28 & -30 \\
\hline Private capital & 172 & 67 & 53 & 77 & 131 & 110 \\
\hline Of which: net direct investment & 153 & 79 & 57 & 88 & 118 & 65 \\
\hline Errors and omissions & 42 & 54 & -22 & 17 & $\mathbf{0}$ & $\mathbf{0}$ \\
\hline Overall balance & 12 & 38 & 25 & -16 & $\mathbf{0}$ & 17 \\
\hline Of which: change in net imputed reserves (increase -) & -10 & -34 & -17 & 22 & 6 & -10 \\
\hline \multicolumn{7}{|c|}{ (In percent of GDP, unless otherwise stated) } \\
\hline \multicolumn{7}{|l|}{ Memorandum items: } \\
\hline Current account & -22.2 & -8.1 & -10.9 & -9.6 & -16.1 & -13.3 \\
\hline \multicolumn{7}{|l|}{ Of which } \\
\hline Exports, f.o.b. & 15.0 & 15.4 & 12.3 & 11.2 & 11.2 & 11.1 \\
\hline Imports, f.o.b. & 53.6 & 43.0 & 43.9 & 43.5 & 47.6 & 45.1 \\
\hline Net private transfers & 4.4 & 4.8 & 5.0 & 5.8 & 5.7 & 5.6 \\
\hline Banana export volume (in thousands of metric tons) & 40.2 & 43.8 & 33.9 & 37.6 & 26.3 & 35.5 \\
\hline Banana export earnings (in millions of U.S. dollars) & 20.4 & 18.3 & 13.7 & 15.9 & 12.0 & 16.2 \\
\hline Export unit value (in U.S. dollars per ton) & 508 & 419 & 404 & 423 & 457 & 457 \\
\hline Total number of visitors (in thousands) & 223 & 256 & 254 & 247 & 230 & 242 \\
\hline Of which: Stay-over visitors (in thousands) & 68.3 & 72.9 & 70.7 & 77.6 & 76.9 & 79.3 \\
\hline Tourism expenditure (in millions of U.S. dollars) & 76.5 & 75.3 & 80.2 & 82.9 & 83.6 & 85.8 \\
\hline
\end{tabular}

Sources: Ministry of Finance and Planning; Eastern Caribbean Central Bank; and Fund staff estimates and projections.

1/ Interest payments are based on accrual accounting. The government has sought a moratorium on Ottley Hall shipyard debt pending an amicable settlement on issues under dispute with the creditors.

2/ Debt forgiveness on U.K. loan totalling EC\$1.06 million in 2000, EC\$0.51million in 2001, and EC\$9.5 million in 2002. Ottley Hall financiers indicated in principle to write off EC $\$ 49.6$ million (5 percent of GDP) in 2004. 
Table 6. St. Vincent and the Grenadines: Monetary Survey

\begin{tabular}{|c|c|c|c|c|c|c|}
\hline & 1999 & 2000 & 2001 & 2002 & $\begin{array}{r}\text { Est. } \\
2003\end{array}$ & $\begin{array}{l}\text { Proj. } \\
2004\end{array}$ \\
\hline \multicolumn{7}{|c|}{ (In millions of Eastern Caribbean dollars) } \\
\hline Net foreign assets & 215.4 & 280.2 & 254.0 & 272.8 & 295.3 & 335.3 \\
\hline ECCB (imputed reserves) & 112.9 & 147.0 & 164.1 & 141.7 & 136.2 & 146.2 \\
\hline Commercial banks & 102.5 & 133.2 & 89.9 & 131.1 & 159.1 & 189.1 \\
\hline Net domestic assets & 365.1 & 355.3 & 400.9 & 436.4 & 434.5 & 423.0 \\
\hline Public sector credit (net) & -90.0 & -78.8 & -77.0 & -45.6 & -90.7 & -101.4 \\
\hline Central government & 56.0 & 62.2 & 44.0 & 86.0 & 58.0 & 52.0 \\
\hline ECCB & 17.0 & 9.6 & 7.5 & 11.7 & 6.9 & 6.9 \\
\hline Commercial banks & 39.0 & 52.6 & 36.5 & 74.3 & 51.0 & 45.0 \\
\hline Net credit to rest of public sector & -146.0 & -141.0 & -120.9 & -131.6 & -148.7 & -153.4 \\
\hline National Insurance Scheme & -147.0 & -151.8 & -138.6 & -138.6 & -156.0 & -158.8 \\
\hline Other & 1.0 & 10.8 & 17.7 & 7.0 & 7.3 & 5.5 \\
\hline Credit to private sector & 545.6 & 592.1 & 605.5 & 633.4 & 642.4 & 651.7 \\
\hline Net credit to nonbank financial inst. & -44.7 & -37.6 & -59.9 & -53.7 & -35.5 & -45.7 \\
\hline Other assets (net) & -45.8 & -120.3 & -67.7 & -97.6 & -81.7 & -81.7 \\
\hline Broad money & 580.5 & 635.5 & 654.9 & 709.3 & 729.8 & 758.3 \\
\hline Money & 182.7 & 212.3 & 219.2 & 239.2 & 246.1 & 255.7 \\
\hline Currency in circulation & 57.5 & 52.1 & 51.5 & 54.0 & 55.6 & 57.8 \\
\hline Demand deposits & 125.2 & 160.1 & 167.7 & 185.1 & 190.5 & 197.9 \\
\hline Quasi-money & 397.7 & 423.3 & 435.7 & 470.1 & 483.7 & 502.6 \\
\hline Time deposits & 112.4 & 137.1 & 143.1 & 156.4 & 160.9 & 167.2 \\
\hline Savings deposits & 268.8 & 277.5 & 285.0 & 304.0 & 312.8 & 325.0 \\
\hline Foreign currency deposits & 16.6 & 8.6 & 7.6 & 9.7 & 10.0 & 10.4 \\
\hline \multicolumn{7}{|c|}{ (Annual percentage changes) } \\
\hline Net foreign assets & 20.0 & 30.1 & -9.4 & 7.4 & 8.2 & 13.5 \\
\hline $\begin{array}{l}\text { Net credit to public sector } \\
\text { Of which }\end{array}$ & 10.9 & 12.4 & 2.4 & 40.7 & -98.8 & -11.7 \\
\hline Central government & 18.6 & 10.9 & -29.2 & 95.5 & -32.6 & -10.3 \\
\hline Credit to private sector & 12.2 & 8.5 & 2.3 & 4.6 & 1.4 & 1.4 \\
\hline Broad money & 12.5 & 9.5 & 3.0 & 8.3 & 2.9 & 3.9 \\
\hline Money & 21.2 & 16.2 & 3.3 & 9.1 & 2.9 & 3.9 \\
\hline Quasi-money 1/ & 8.9 & 6.4 & 2.9 & 7.9 & 2.9 & 3.9 \\
\hline \multicolumn{7}{|c|}{ (Percent contribution to growth in broad money) $2 /$} \\
\hline Net foreign assets & 7.0 & 11.2 & -4.1 & 2.9 & 3.2 & 5.5 \\
\hline Net domestic assets & 5.5 & -1.7 & 7.2 & 5.4 & -0.3 & -1.6 \\
\hline Net credit to public sector & 2.1 & 1.9 & 0.3 & 4.8 & -6.4 & -1.5 \\
\hline \multicolumn{7}{|l|}{ Of which } \\
\hline Central government & 1.7 & 1.1 & -2.9 & 6.4 & -3.9 & -0.8 \\
\hline Credit to private sector & 11.5 & 8.0 & 2.1 & 4.3 & 1.3 & 1.3 \\
\hline Net credit to nonbank financial inst. & -5.0 & 1.2 & -3.5 & 0.9 & 2.6 & -1.4 \\
\hline Other assets (net) & -3.1 & -12.8 & 8.3 & -4.6 & -0.8 & 0.0 \\
\hline Broad money & 12.5 & 9.5 & 3.0 & 8.3 & 2.9 & 3.9 \\
\hline \multicolumn{7}{|l|}{ Memorandum item: } \\
\hline Income velocity 3/ & 1.6 & 1.5 & 1.4 & 1.4 & 1.4 & 1.4 \\
\hline
\end{tabular}

Sources: ECCB; Ministry of Finance and Planning; and Fund staff estimates.

$1 /$ Including resident foreign currency deposits.

2/ Change in relation to the stock of broad money at the beginning of the period.

3/ Nominal GDP at market prices divided by broad money. 
Table 7. St. Vincent and the Grenadines: Indicators of External and Financial Vulnerability (Annual percentage changes, unless otherwise specified)

\begin{tabular}{|c|c|c|c|c|c|c|}
\hline & 1999 & 2000 & 2001 & 2002 & $\begin{array}{r}\text { Est. } \\
2003\end{array}$ & $\begin{array}{l}\text { Proj. } \\
2004\end{array}$ \\
\hline \multicolumn{7}{|l|}{ External indicators } \\
\hline Merchandise exports & -1.0 & 4.3 & -17.4 & -5.4 & 2.8 & 2.6 \\
\hline Merchandise imports & 4.2 & -18.5 & 5.3 & 3.5 & 12.5 & -1.5 \\
\hline Terms of trade deterioration (-) & -9.4 & -3.3 & 2.9 & 2.1 & -5.2 & -0.8 \\
\hline Tourism earnings & 5.3 & -1.5 & 6.4 & 3.4 & 0.9 & 2.6 \\
\hline Banana export earnings & -5.2 & -6.0 & -25.4 & 16.0 & -24.3 & 35.0 \\
\hline Current account balance (in percent of GDP) & -22.2 & -8.1 & -10.9 & -9.6 & -16.1 & -13.3 \\
\hline $\begin{array}{l}\text { Capital and financial account balance (in percent of GDP) 1/ } \\
\text { Of which }\end{array}$ & 23.5 & 12.3 & 13.5 & 7.9 & 16.2 & 15.0 \\
\hline Foreign direct investment (in percent of GDP) & 17.2 & 8.7 & 6.1 & 9.0 & 11.8 & 6.2 \\
\hline \multicolumn{7}{|l|}{ Gross international reserves of the ECCB $2 /$} \\
\hline In millions of U.S. dollars & 364.6 & 383.7 & 446.0 & 504.8 & 543.3 & $\ldots$ \\
\hline In percent of broad money & 18.2 & 17.4 & 19.1 & 20.2 & 20.5 & $\ldots$ \\
\hline Commercial banks' net foreign assets (in millions of U.S. dollars) & 38.0 & 49.3 & 33.3 & 48.6 & 58.9 & 70.0 \\
\hline External public debt (in percent of GDP) & 48.5 & 47.8 & 49.1 & 47.1 & 50.5 & 45.0 \\
\hline \multicolumn{6}{|l|}{ External debt service (in percent of exports of goods and } & 7.3 \\
\hline \multicolumn{7}{|l|}{ Of which } \\
\hline Interest & 3.1 & 2.5 & 3.0 & 2.6 & 2.5 & 1.7 \\
\hline \multicolumn{6}{|l|}{ Nominal exchange rate (E.C. dollars per U.S. dollar, } & $\begin{array}{l}\cdots \\
\cdots\end{array}$ \\
\hline Real effective exchange rate depreciation (-), end period $3 /$ & -0.1 & 5.1 & 0.5 & -7.2 & -13.4 & $\ldots$ \\
\hline \multicolumn{7}{|l|}{ Financial indicators } \\
\hline Broad money & 12.5 & 9.5 & 3.0 & 8.3 & 2.9 & 3.9 \\
\hline Credit to the private sector & 12.2 & 8.5 & 2.3 & 4.6 & 1.4 & 1.4 \\
\hline \multicolumn{7}{|l|}{ Prudential indicators (in percent) $2 /$} \\
\hline Capital adequacy ratio (local banks) & 15.7 & 17.2 & 17.7 & 18.6 & 17.0 & $\ldots$ \\
\hline NPLs to total loans ratio & 13.1 & 10.9 & 13.0 & 11.3 & 13.1 & $\ldots$ \\
\hline \multicolumn{7}{|l|}{ Of which } \\
\hline Local banks & 20.4 & 16.9 & 18.8 & 15.3 & 19.3 & $\ldots$ \\
\hline Foreign banks & 3.8 & 3.0 & 5.5 & 5.1 & 4.5 & $\ldots$ \\
\hline Loan loss provision to NPLs ratio & 20.4 & 35.2 & 30.4 & 41.5 & 30.0 & $\ldots$ \\
\hline \multicolumn{7}{|l|}{ Of which } \\
\hline Local banks & 18.5 & 31.9 & 30.4 & 40.0 & 25.2 & $\ldots$ \\
\hline Foreign banks & 34.1 & 59.9 & 30.4 & 48.1 & 59.0 & $\ldots$ \\
\hline Gross government claims to total assets ratio 4/ & 14.2 & 14.4 & 15.2 & 19.2 & 20.9 & $\ldots$ \\
\hline Foreign currency deposits to total deposits ratio & 7.1 & 5.9 & 4.5 & 3.4 & 3.3 & $\ldots$ \\
\hline Net foreign currency exposure to capital (local banks) & 67.9 & -54.6 & 45.4 & 49.0 & 172.2 & $\ldots$ \\
\hline Contingent liabilities to capital (local banks) & 107.4 & 58.9 & 76.5 & 59.0 & 53.1 & $\ldots$ \\
\hline (Pre-tax) return on average assets & 1.7 & 0.8 & 1.0 & 1.2 & 0.8 & $\ldots$ \\
\hline Three-month TB rate & 7.0 & 7.0 & 7.0 & 7.0 & 5.8 & $\ldots$ \\
\hline
\end{tabular}

Sources: Eastern Caribbean Central Bank; Ministry of Finance; and Fund staff estimates and projections.

$1 /$ Includes errors and omissions.

2/ End-June figures for 2003.

$3 /$ The figure for 2003 is the twelve-month change to October.

4/ End-March figure for 2003. 
Table 8. St. Vincent and the Grenadines: Comparative Economic Performance

\begin{tabular}{|c|c|c|}
\hline & $\begin{array}{l}\text { St. Vincent and } \\
\text { the Grenadines }\end{array}$ & ECCU 1/ \\
\hline \multicolumn{3}{|l|}{ I. Social and Demographic Indicators } \\
\hline Area, sq. km. & 389 & 2810 \\
\hline Arable land, percent & 10 & 9 \\
\hline \multicolumn{3}{|l|}{ Population characteristics, 2002} \\
\hline Population ('000; 2002 est.) & 109 & 583 \\
\hline Life expectancy at birth, years & 73 & 73 \\
\hline Crude death rate per thousand & 6 & 7 \\
\hline Crude birth rate per thousand & 18 & 19 \\
\hline \multicolumn{3}{|l|}{ Social indicators } \\
\hline Literacy, percent of population over 15 years (2002) & 96 & 92 \\
\hline Population per physician $2 /$ & 1110 & 1453 \\
\hline Population per hospital bed 2/ 3/ & 526 & 288 \\
\hline \multicolumn{3}{|l|}{ II. Economic Indicators } \\
\hline GDP per capita (US\$; 2002 est.) & 3308 & 4995 \\
\hline Real GDP growth at factor cost (percent; 1999-2002) & 1.7 & 1.3 \\
\hline Unemployment rate (percent; 2001 est.) & 20.8 & 15.0 \\
\hline Inflation (percent; e.o.p.; 1999-2002) & -0.2 & 2.0 \\
\hline Prime lending rate (2002) & 11.5 & 11.3 \\
\hline Central government revenue and grants (percent of GDP; 1999-2002) & 30.6 & 27.7 \\
\hline Central government expenditure (percent of GDP; 1999-2002) & 33.0 & 34.4 \\
\hline Central government wage bill (percent of GDP; 1999-2002) & 14.3 & 12.6 \\
\hline Central government overall balance (percent of GDP; 1999-2002) & -2.6 & -6.7 \\
\hline Central government current balance (percent of GDP; 1999-2002) & 1.8 & -0.5 \\
\hline Tourism growth, stay-overs (percent; 1999-2002) & 3.8 & 0.6 \\
\hline Export volume growth (percent, 1999-2002) & -2.3 & 2.1 \\
\hline External current account balance (percent of GDP; 1999-2002) & -12.7 & -16.5 \\
\hline Public sector external debt (percent of GDP, 2002) 4/ & 47.1 & 60.6 \\
\hline Total public sector debt (percent of GDP, 2002) 4/ 5/ & 71.5 & 99.1 \\
\hline
\end{tabular}

Sources: CIA World Factbook; Eastern Caribbean Central Bank; and Fund staff estimates.

1/ Comprises the ECCB member countries, which are Antigua and Barbuda, Dominica, Grenada,

St. Kitts and Nevis, St. Lucia, and St. Vincent and the Grenadines.

2/ Data unavailable for Antigua and Barbuda.

3/ Data unavailable for St. Kitts and Nevis.

4/ Government and government-guaranteed debt, end of period.

5/ This includes borrowing from the NIS. 


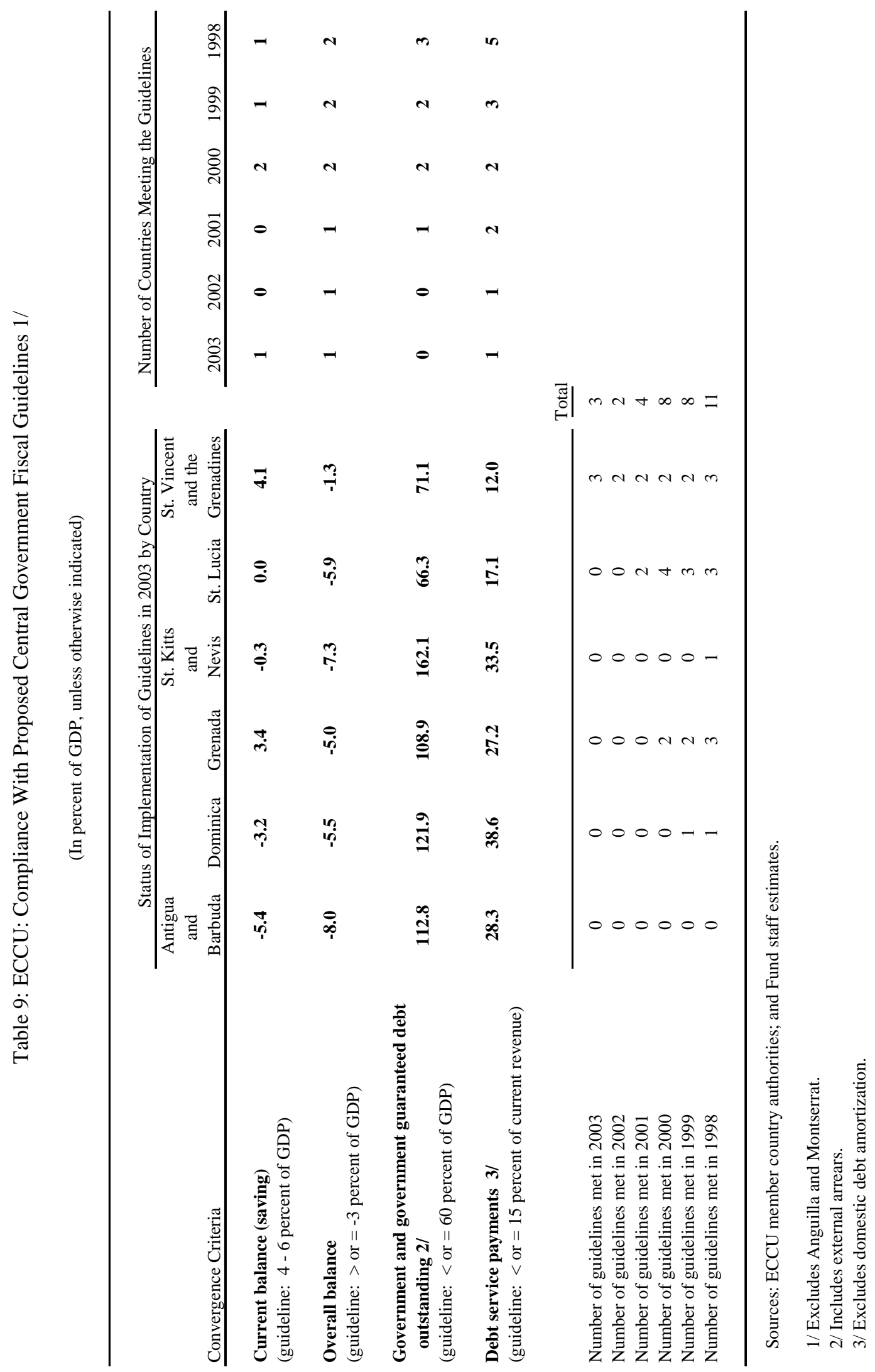


Table 10. St. Vincent and the Grenadines: Medium-Term Projections

\begin{tabular}{lllllll}
\hline & 2003 & 2004 & 2005 & 2006 & 2007 & 2008 \\
\hline
\end{tabular}

(In percent of GDP, unless otherwise specified)

Real GDP growth, at factor cost, percent change

Nonfinancial public sector

Central government overall balance (cash basis)

Gross public sector debt 1/ 2/

Public sector overall balance 1/

Public sector primary balance

$\begin{array}{rr}1.6 & \\ & \\ -1.3 & -2.0 \\ 71.0 & 67.1 \\ -2.6 & -2.4 \\ 0.4 & 0.2\end{array}$

I. Baseline Scenario

$\begin{array}{rrrrr}2.4 & 1.8 & 1.6 & 1.8 & 1.8 \\ & & & & \\ -2.0 & -2.1 & -2.2 & -2.4 & -2.7 \\ 67.1 & 69.4 & 72.1 & 74.5 & 77.0 \\ -2.4 & -2.7 & -2.9 & -3.1 & -3.4 \\ 0.2 & -0.1 & -0.4 & -0.5 & -0.7\end{array}$

II. Alternative Scenario

\section{Output and prices}

Real GDP growth, at factor cost, percent change

Consumer prices, end of period percent change

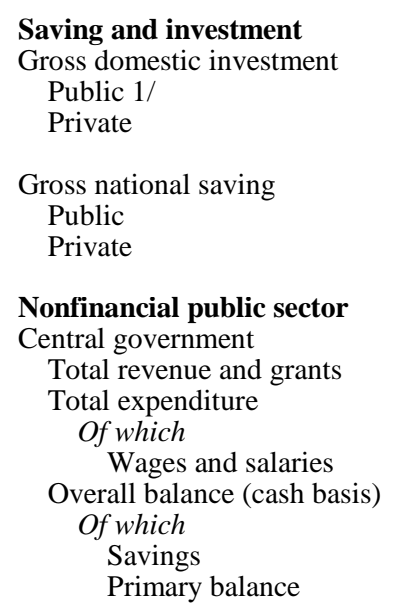

Gross public sector debt $1 / 2 /$

Public sector overall balance 1/

Public sector primary balance

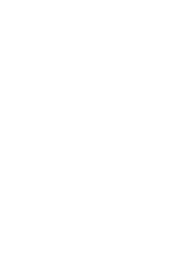

\section{External sector}

External current account

Gross public sector external debt (end of period)

External public debt service

(In percent of exports of goods and services)

(In percent of central government revenue before grants)

Source: Fund staff projections.

1/ The consolidated public sector includes the central government, the National Insurance Scheme (NIS), Kingstown Board, and 10 nonfinancial public enterprises.

2/ Net of intra-public sector debt (mainly central government debt to the NIS). 


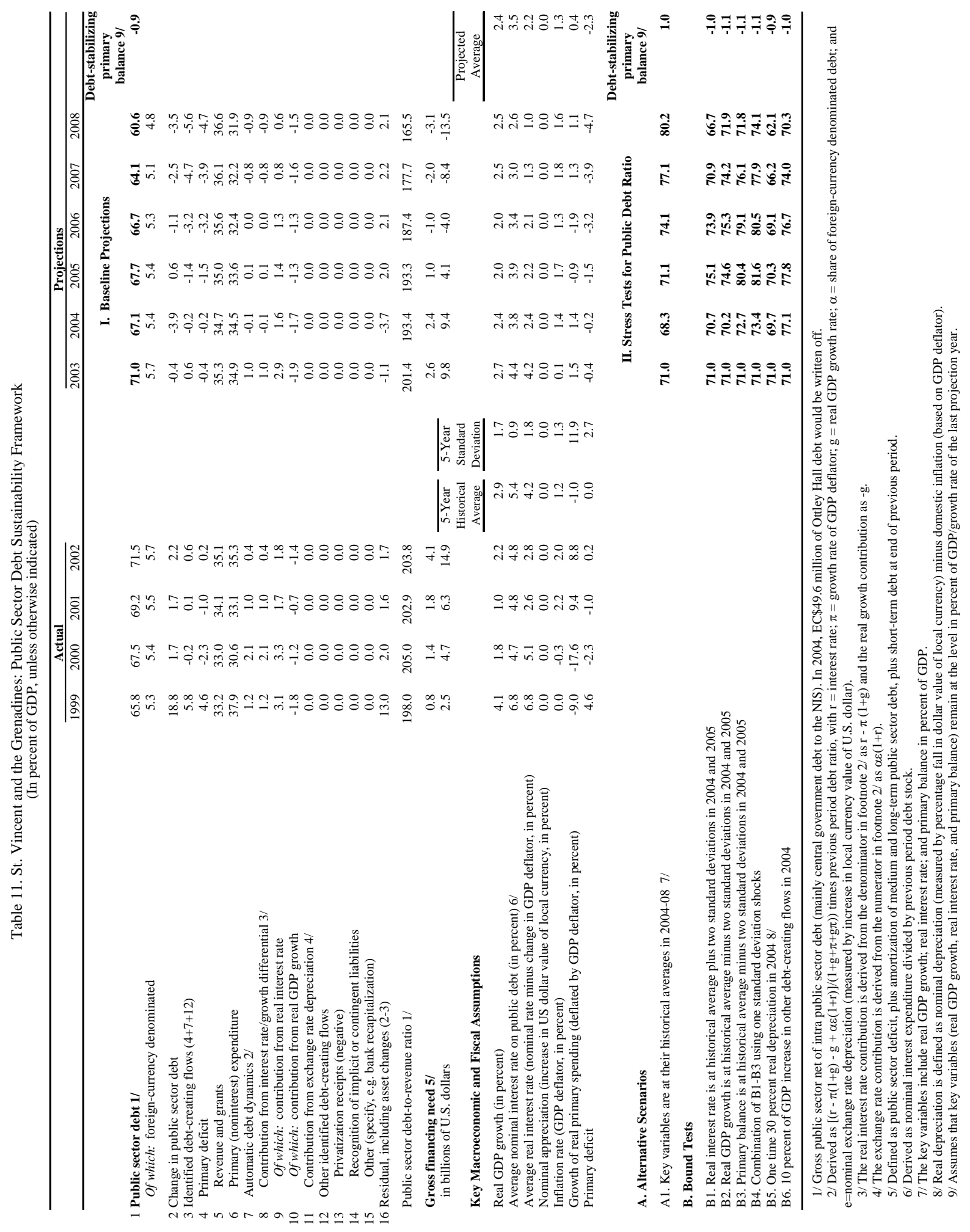




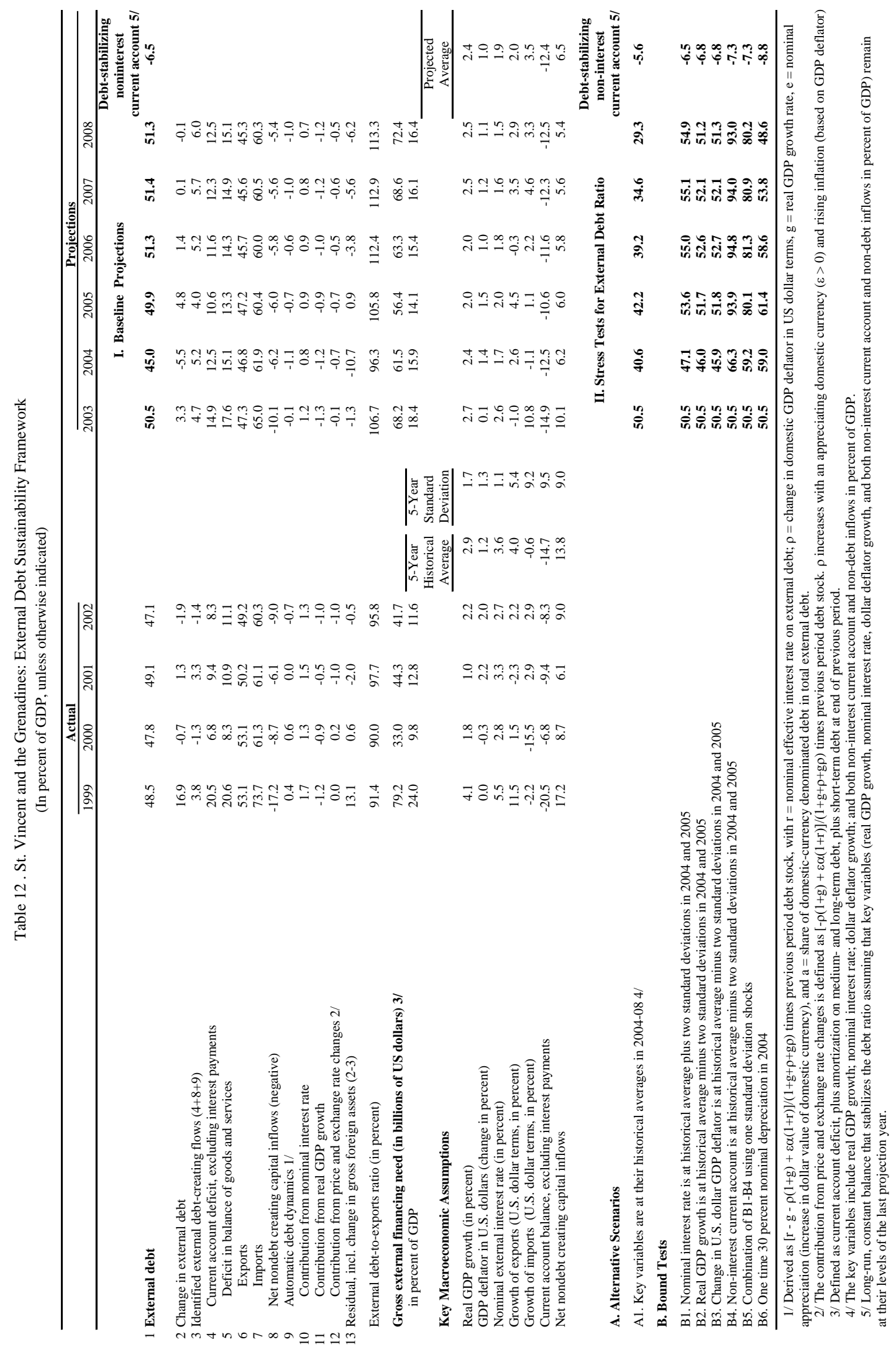




\section{St. Vincent and the Grenadines: Fund Relations}

(As of December 31, 2003)

I. Membership status: Joined 12/28/79; Article VIII.

II. General resources account:

Quota

Fund holdings of currency

Reserve position in Fund

III. SDR department:

Net cumulative allocation

Holdings
SDR Million

8.30

7.80

0.50

SDR Million

0.35

0.00
Percent of Quota

100.0

94.0

6.0

Percent of

Allocation

100.0

1.24

IV. Outstanding purchases and loans: None.

V. Financial arrangements: None.

VI. Projected Payments to Fund (SDR Million; based on existing use of resources and present holdings of SDRs):

Principal

Charges/Interest

Total

\begin{tabular}{lcccc}
\multicolumn{5}{c}{ Forthcoming } \\
2004 & 2005 & 2006 & 2007 & 2008 \\
\hline & & & & \\
0.01 & 0.01 & 0.01 & 0.01 & 0.01 \\
0.01 & 0.01 & 0.01 & 0.01 & 0.01
\end{tabular}

VII. Exchange rate arrangement: Since July 1976, the Eastern Caribbean dollar has been pegged to the U.S. dollar at the rate of EC $\$ 2.70$ per U.S. dollar. The exchange system is free of restrictions on the making of payment and transfers for current international transactions.

VIII. Article IV consultation: The last Article IV consultation was concluded by the Executive Board on January 27, 2003. St. Vincent is on the 12-month consultation cycle. The authorities have not accepted the Fourth Amendment to the Fund's Articles of Agreement.

IX. Technical assistance: (2001-present)

Caribbean Regional Technical Assistance Centre (CARTAC): 
- Financial sector: Regional workshop on regulation of trust service, August 2003; assistance provided to the Offshore Finance Authority (OFA) on a file review of the offshore banks, etc., May 2003; regional workshop on insurance supervision practices, February 2003; regional workshop on consolidated supervision (assisted by MFD and the Central Bank of Barbados), January 2003; assistance on revising/creating the ECCB manuals for procedures for off-site surveillance, onsite inspections and anti-money laundering compliance for both the domestic and offshore sectors, since December 2002; sponsoring a training seminar on financial sector supervision held at the ECCB for regulators of banks, insurance companies and credit unions from all OECS member states and the ECCB, October 2002; organizing an inspection team drawn from the ECCB and two other supervisory organizations, to assist the OFA with on-site inspections of offshore banks, late 2002; conducting a review of the offshore banking legislation for St. Vincent and the Grenadines for consistency with the Basle Core Principles, August 2002.

- Public finances and financial programming: Completing a comprehensive study of St. Vincent and the Grenadines' tax system and administration (with FAD) as part of the overall study for the OECS region, early 2003; regional training courses in tax audit and administration, 2002; assisting the government in a seminar on corporate governance, September 2002; assisting the ECCB and member country governments in a stabilization/financial programming workshop under the Stabilization and Adjustment Technical Assistance Program (SATAP), September 2002 (assistance to St. Vincent and Grenadines_training-continued in December 2002 and April 2003); assisting the ECCB in a two day seminar on launching major public finance reform programs in the ECCB member countries, June 2002; organizing an ECCB workshop (jointly sponsored by the ECCB and the Fund) for officials of member countries on "Estimating and Forecasting Techniques for Financial Programming”, September 2001.

- Statistics: Assisting the OECS member country governments on developing indicators for the compilation of quarterly BOP for ECCU countries and updating GDDS metadata for the financial and external sectors, September 2002; assisting the OECS member country governments in the first workshop (part of a series over an 18-month period) on the Statistics Sweden Program for implementing the 1993 System of National Accounts, September 2002; assisting the government linking the new CPI basket based on the 1995/96 Household Budget and Expenditure Survey (HBES) to the old basket based on 1976 HBES (the base year was changed from 1981 to 2001), July 2002.

\section{FAD:}

- In early 2003, FAD and CARTAC completed a comprehensive study of St. Vincent and the Grenadines' tax system and administration as part of the overall study for the OECS region. 
MFD:

- In September 2001, a mission assisted the government to complete the OFC Module 1, and prepare an aide-mémoire on the principal issues.

STA:

- In July 2002, a mission assisted the ECCB and member country governments in a debt management workshop.

In July 2001, a mission assisted ECCB countries to complete GDDS metadata for sociodemographic topics, and GDDS external metadata. 


\section{St. Vincent and the Grenadines: Relations with the World Bank Group}

(As of January 31, 2004)

The World Bank's Management presented to its Board the Eastern Caribbean Sub-Region Country Assistance Strategy (CAS), on June 28, 2001. The CAS, which covers FY 2002-06, proposes new commitments of US\$107 million for five borrowing member states of the Organization of the Eastern Caribbean States (OECS), including St. Vincent and the Grenadines. The main goals of the strategy are to reduce income insecurity and vulnerability at the national and household levels, and build human and institutional capacity to meet the challenging economic and social environment facing these small states. Most new projects are being provided under a sub-regional umbrella mechanism using horizontal Adaptable Program Loans (APLs), and in close collaboration with sub-regional organizations and external partners.

\section{Projects}

There are three active World Bank projects in St. Vincent and the Grenadines for a net commitment of approximately US\$9.1 million.

The St. Vincent and the Grenadines Disaster Management Project, approved in May 2002, is part of a regional program for the five OECS borrowing countries to fortify, reconstruct, and/or rehabilitate key economic and social infrastructure and facilities, in order to minimize damage or disruption caused by future natural and man-made disasters, and to speed emergency recovery following such disasters. Additionally, the project is expected to strengthen the countries' institutional capacity to prepare for and respond to disaster emergencies efficiently and effectively. The total program size is US\$46 million, and the St. Vincent and the Grenadines component is US\$5.9 million.

The World Bank on March 8, 2002, approved \$20.9 million in loans and credits to support Emergency Recovery Projects in Dominica, Grenada, St. Kitts and Nevis, St. Lucia, and St. Vincent and the Grenadines. The projects support efforts aimed at fostering recovery from the fallout of the events of September 11, 2001. The projects support: (i) efforts to safeguard the productive capacity of the tourism sector by securing energy imports; (ii) investments to enhance security at airports and ports; and (iii) the development of institutional capacity to develop security programs as mandated by international civil aviation and maritime transport agencies. The Bank's support to St. Vincent and the Grenadines under this project is for US\$3.2 million.

The OECS Telecommunications Reform Program, approved in June 1998 for US\$6 million, aims to introduce pro-competition reforms in the telecommunications sector and increase the supply of informatics-related skills in the five OECS borrowing countriesDominica, Grenada, St. Kitts and Nevis, St. Lucia, and St. Vincent and the Grenadines. The project has assisted the OECS countries negotiate with the subregional telecom monopoly for less one-sided contracts and lower long distance and regional telephone rates. The St. Vincent and the Grenadines is US\$1.2 million. 


\section{ECONOMIC AND SECTOR WORK}

The Bank is and has recently been engaged in three categories of analytical work of direct relevance to St. Vincent and the Grenadines. The first builds on the Bank-wide program on small states. Earlier pieces focused, among others, on the issues of vulnerability in the Caribbean (including macroeconomic volatility and income security), research on catastrophic insurance, reviews of natural hazard risk mitigation strategies, and institutional arrangements for environmental management in the OECS. Several of these were discussed by the Caribbean Group for Cooperation in Economic Development in June 2002.

The second body of work addresses long-term development in the OECS and includes the completed Institutional and Organizational Capacity Review of the OECS, a Procurement Assessment Review, and a Financial Accountability Assessment. A fiscal issues report, which includes a review of public expenditures in St. Vincent and the Grenadines, is ongoing, as is work on an Energy Sector Management Assistance Program for the OECS as a whole. The Bank is also about to embark on a study of growth and competitiveness in the OECS, scheduled for completion in 2004.

Third, the Bank will continue to work together with the IMF and ECCB to fully review the financial sector through an ongoing Financial Sector Assessment Program.

\section{FinANCIAL RELATIONS}

(In millions of U.S. dollars)

\begin{tabular}{|c|c|c|c|c|c|c|c|c|c|}
\hline \multicolumn{5}{|c|}{ Operation } & \multicolumn{3}{|c|}{ Original Principal } & Available/1 & Disbursed/1 \\
\hline \\
\hline \multicolumn{5}{|c|}{ Grenadines } & \multicolumn{3}{|c|}{3.20} & 2.04 & 1.61 \\
\hline \multirow{2}{*}{\multicolumn{5}{|c|}{$\begin{array}{l}\text { Disaster management-St. Vincent and the Grenadines } \\
\text { OECS telecom reforms-St. Vincent and the Grenadines }\end{array}$}} & \multicolumn{3}{|c|}{5.91} & 6.22 & 0.34 \\
\hline & & & & & \multicolumn{3}{|c|}{1.20} & 0.65 & 0.57 \\
\hline \multirow{3}{*}{\multicolumn{10}{|c|}{ 1/ Amounts may not add up to Original Principal due to changes in the SDR/US exchange rate since signing. }} \\
\hline & & & & & & & & & \\
\hline & & & & & & & & & \\
\hline & \multicolumn{8}{|c|}{ Actual } & Projections \\
\hline & 1996 & 1997 & 1998 & 1999 & 2000 & 2001 & 2002 & 2003 & 2004 \\
\hline Total disbursements & 0.1 & 0.1 & -0.0 & 0.2 & 0.0 & 0.4 & 1.5 & 1.7 & 1.0 \\
\hline Repayments & 0.2 & 0.2 & 0.2 & 0.1 & 0.1 & 0.1 & 0.1 & 0.3 & 0.1 \\
\hline Net disbursements & -0.1 & -0.1 & -0.2 & 0.1 & -0.1 & 0.3 & 1.4 & 1.4 & 0.9 \\
\hline Canceled & 0.0 & 0.7 & 0.0 & 0.0 & 0.0 & 0.0 & 0.0 & 0.0 & 0.0 \\
\hline Interest and fees & 0.1 & 0.1 & 0.1 & 0.1 & 0.1 & 0.1 & 0.1 & 0.1 & 0.1 \\
\hline
\end{tabular}




\section{St. Vincent and the Grenadines: Relations with the Caribbean Development Bank} (As of November 30, 2003)

CDB has approved loans totaling US\$111.45 million, of which US\$20.22 are undisbursed.

\section{Major Projects:}

The Grenadines Multi-Project III-US\$0.3 million undisbursed-is geared towards further development of the Multi-Project II tourist sector in the Grenadines through construction of roads in Bequia, Canouan and Union Islands, and a jetty in Mayreau.

The Basic Education Project-US\$0.7 million undisbursed-is for the construction of schools, teacher training, and curriculum development.

Third Line of Credit-US\$1.0 million undisbursed — to provide mortgage finance, student loans and to provide credit to people engaged in micro and small scale enterprises.

Sixth Student Loan Scheme-US\$3.5 million undisbursed—to provide loans to students for upgrading skills at the professional, technical and vocational levels.

$3^{\text {rd }}$ Road Project-Windward Highway-US\$10.5 million undisbursed - to reconstruct approximately 23 kilometers of the Windward Highway; the realignment of the road at 6 locations; widening and lining of the Byera tunnel to provide pedestrian access; and rehabilitation of 13 bridges.

Caribbean Court of Justice - to provide for the establishment and operation of a final Court of Appeal to replace the Judicial Committee of the Privy Council and to act as a final arbiter in disputes arising between CARICOM member states or between a CARICOM national and another country. 


\section{Current Portfolio}

(In millions of U.S. dollars unless otherwise specified)

Approved Undisbursed

Rate of

Disbursement

(In percent)

Total

Lines of credit

Multi-project

Student loan

Basic education

$3^{\text {rd }}$ Road Project-Windward Highway

Caribbean Court of Justice
30.35

2.38

5.61

3.50

6.08

10.58

2.20
18.23

1.02

0.51

3.50

0.89

10.56

2.20
39.9

57.1

94.5

0

88.5

0.8

\section{LOAN DISBURSEMENTS}

(In millions of U.S. dollars)

\begin{tabular}{|c|c|c|c|c|c|}
\hline & 1999 & 2000 & 2001 & 2002 & $20031 /$ \\
\hline Net disbursement & 0.94 & 0.07 & 3.85 & 3.77 & 1.36 \\
\hline Disbursement & 3.37 & 2.15 & 5.88 & 5.93 & 3.88 \\
\hline Amortization & 2.43 & 2.08 & 2.03 & 2.16 & 2.52 \\
\hline Interest and charges & 1.78 & 1.42 & 1.86 & 1.79 & 1.70 \\
\hline Net and charges & -0.84 & -1.35 & 1.99 & 1.98 & -0.34 \\
\hline
\end{tabular}

1/ January to November only. 


\section{St. Vincent and the Grenadines: Statistical Issues}

St. Vincent and the Grenadines' statistical database remains weak in terms of coverage, consistency, periodicity, and timeliness. Efforts to address the weaknesses in the statistical base have been hampered by low response rates to surveys (less than 50 percent), and high turnover of staff.

Prices: Data on the consumer price index are reported regularly with a two-month lag. CARTAC assisted in linking the CPI based on 1981 series to the CPI based on 2001 series. This was part of the Fund assisted program on Constructing Weights for the Harmonized Consumer Price Index in the ECCU. St. Vincent and the Grenadines conducted the Household Budget and Expenditure Survey (HBES) in 1995/96, whilst all the other five ECCU member countries conducted HBES surveys for 1998/99. Compilers thus will have to use a method for updating the St. Vincent expenditure weights to 1998/99 to properly align its CPI with those of the other ECCU member countries before all eight are combined into an ECCU-harmonized CPI.

Labor: The Statistical Office has not published official data on unit labor costs and employment.

National Accounts: National accounts data by sector are provided with one year lag, and the coverage of economic activity in the informal sector is inadequate. There is a need to fully upgrade compilation of statistics from the 1968 System of National Accounts to the 1993 System of National Accounts.

Public finance: STA publishes annual data for the consolidated central government in the GFS Yearbook. This publication includes detailed information on revenues and expenditures but not on financing. Due to delays in reporting capital expenditures by some ministries, quarterly revenue and expenditure data for the central government are provided to the Fund after some lag. Discrepancies exist between the fiscal and monetary accounts, between above and below the line for budget data, between financing data and debt accumulation. There is a need to reconcile these discrepancies. Although domestic debt figures are now available following implementation of the CS-DRMS system, the domestic debt amortization figures are incomplete. The public enterprises financial reports are not timely, with about a two year lag.

Monetary statistics: Monetary data are compiled by the ECCB on a monthly basis. The data are reported regularly to the Fund, although the timeliness of data could be improved. The monetary and financial data do not include other deposit taking institutions such as the credit unions. The ECCB is aware of the need to improve the coverage of the financial statistics and has taken steps to collect data on credit unions (the savings and loans of credit unions account for 20-30 percent of market share).

Balance of payments: The ECCB compiles annual balance of payment statistics for St. Vincent and the Grenadines, which are submitted to STA. The latest published data in the IFS (February 2004) are for 2001. There is a need to improve the compilation of capital and financial account transactions in the balance of payments. In addition, the recording of the stock of private and public debt should be improved. 


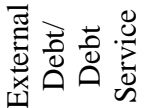

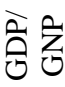

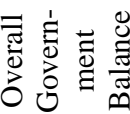

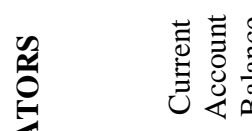

\begin{tabular}{|c|c|c|c|c|c|c|c|}
\hline$\stackrel{\Im}{\beth}$ & $\begin{array}{l}\frac{0}{2} \\
\frac{n}{8}\end{array}$ & $\varangle$ & $z_{i}$ & 总 & $\frac{11}{\Sigma}$ & D & $\varangle$ \\
\hline ర్రి & 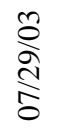 & $\varangle$ & $\stackrel{>}{*}$ & $\begin{array}{l}0 \\
\forall\end{array}$ & $\Psi$ & D & $\varangle$ \\
\hline @̊ & 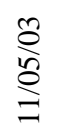 & $\alpha$ & $\vec{\sigma}$ & $\stackrel{\Gamma}{\frac{1}{2}}$ & W & D & $\varangle$ \\
\hline §ิ & $\begin{array}{l}\text { Oo } \\
\frac{0}{2}\end{array}$ & $\varangle$ & $>$ & O্ర & $\sum^{\frac{W}{2}}$ & D & $\varangle$ \\
\hline$\stackrel{\varrho}{\varrho}$ & $\begin{array}{l}\text { O̊ } \\
\frac{\Delta}{a}\end{array}$ & $\Sigma$ & $\overrightarrow{0}$ & $\begin{array}{l}0 \\
b\end{array}$ & $\stackrel{\frac{1}{2}}{\Sigma}$ & D & 0 \\
\hline 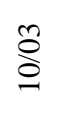 & $\begin{array}{l}\text { @) } \\
\frac{0}{d}\end{array}$ & $\Sigma$ & $\Sigma$ & $\begin{array}{l}0 \\
z\end{array}$ & $\sum_{2}^{T}$ & D & $\Sigma$ \\
\hline$\stackrel{\varrho}{\varrho}$ & $\begin{array}{l}\stackrel{0}{0} \\
\frac{0}{\Delta}\end{array}$ & $\Sigma$ & $\vec{\alpha}$ & 总 & 足 & D & 0 \\
\hline$\stackrel{\varrho}{\varrho}$ & 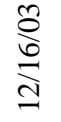 & $\Sigma$ & $\vec{\alpha}$ & 总 & $\frac{U}{\dot{x}}$ & D & 0 \\
\hline$\stackrel{\wp}{\varrho}$ & $\begin{array}{l}\text { 尽 } \\
\frac{0}{d}\end{array}$ & $\Sigma$ & $\vec{\sigma}$ & 总 & 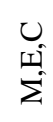 & D & 0 \\
\hline$\stackrel{\text { }}{\varrho}$ & $\begin{array}{l}\text { \%) } \\
\frac{0}{0}\end{array}$ & $\Sigma$ & $\overrightarrow{0}$ & 总 & $\frac{U}{\Sigma}$ & D & 0 \\
\hline$\frac{\hat{\wp}}{8}$ & 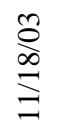 & $\Sigma$ & $\overrightarrow{0}$ & 总 & 迎 & D & $\alpha$ \\
\hline 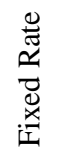 & 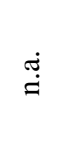 & $\stackrel{\mathscr{J}}{=}$ & $\stackrel{\mathscr{J}}{=}$ & 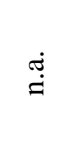 & $\stackrel{\mathscr{J}}{=}$ & $\stackrel{d}{g}$ & 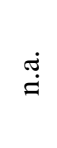 \\
\hline
\end{tabular}

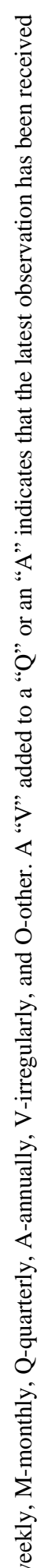

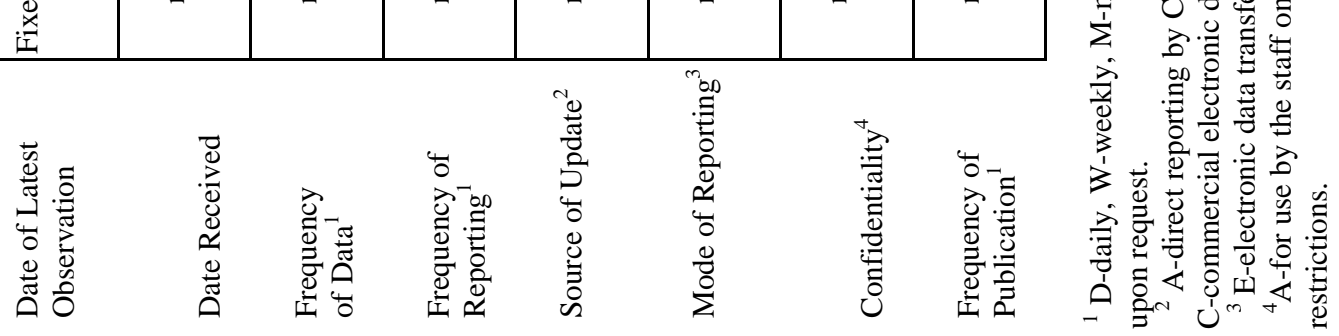




\section{INTERNATIONAL MONETARY FUND}

\section{ST. VINCENT AND THE GRENADINES \\ Staff Report for the 2003 Article IV Consultation Supplementary Information}

Prepared by the Western Hemisphere and Policy Development and Review Departments Approved by José Fajgenbaum and Matthew Fisher

May 3, 2004

\section{RECENT DEVELOPMENTS}

1. Real GDP grew more rapidly than anticipated in 2003, while inflation was also higher. Preliminary national accounts estimates indicate real GDP growth of 3.6 percent in 2003, 2 percentage points higher than previously estimated. The strong growth outcome stems from increased activity in the electricity, construction, and trade and transport sectors. The 12-month CPI inflation increased to 2.7 percent (projected inflation was 1.5 percent), largely on account of a sharp increase in food prices in the last three months of the year.

2. Preliminary data show that the fiscal outturn for $\mathbf{2 0 0 3}$ was substantially weaker than expected. The overall balance of the central government was 31/4 percent of GDP weaker than projected. While this deviation reflects in part weaker-than-expected tax collections, lower grant disbursements, and somewhat higher capital expenditures (due to the government purchase of equity in the regional airline following an agreement on its restructuring), almost half of the deviation represents a discrepancy between identified revenues and expenditures and identified financing items, which has yet to be clarified.

3. Despite an increase in the public sector debt stock, interest rates on government debt instruments continue to decline. Total gross public sector debt is estimated at 73 percent of GDP at end-2003, slightly higher than projected earlier, as the larger deficit was financed through higher external disbursements and use of the overdraft facility with the state-owned National Commercial Bank (NCB). Nonetheless, interest rates on government debt instruments placed on the Regional Government Securities Market have continued to decline - at end-September 2003, three-month treasury bills were placed at a yield of 5.7 percent, which had declined to 4.75 percent by end-April 2004 .

4. The approved budget for 2004 envisages an improvement in the overall balance of the central government of $2^{1 / 2}$ percent of GDP, if grants and capital expenditures remain at historical levels. While the budget envisages a significant increase in capital spending, the implementation rate of the public sector investment program has typically been less than envisaged in the budget. The authorities expect both current expenditures and 
current revenues to increase by about $2 \frac{1}{2} 2$ percent of GDP - revenue increases are anticipated to stem largely from administrative improvements and a pick-up in economic activity.

\section{StAFF Appraisal}

\section{Recent developments serve to reinforce the thrust of the staff appraisal} contained in the staff report (4/1/04), but highlight further the need to ensure fiscal discipline. While the debt stock remains among the lowest in the region and debt service remains manageable, given the large concessional element, the deterioration in the fiscal stance at end-2003 and the consequent increase in debt raise concerns. The approved 2004 budget, appropriately, is likely to entail a narrowing of the fiscal imbalances, and the staff strongly encourages the authorities to achieve an overall deficit of $2 \frac{1}{4}$ percent of GDP, in line with the average outturn in 1999-2001. 
Table 1. St. Vincent and the Grenadines: Summary of Central Government Operations

\begin{tabular}{|c|c|c|c|c|c|c|c|}
\hline & 1999 & 2000 & 2001 & $\begin{array}{l}\text { Prel. } \\
2002 \\
\end{array}$ & $\begin{array}{r}\text { Proj. } \\
20031 /\end{array}$ & $\begin{array}{l}\text { Prel. } \\
2003\end{array}$ & $\begin{array}{l}\text { Budget } \\
20042 /\end{array}$ \\
\hline \multicolumn{8}{|c|}{ (In millions of Eastern Caribbean dollars) } \\
\hline Total revenue and grants & 270 & 267 & 286 & 313 & 327 & 313 & 355 \\
\hline Current revenue & 252 & 256 & 268 & 302 & 316 & 307 & 344 \\
\hline Tax & 215 & 216 & 231 & 260 & 270 & 260 & 301 \\
\hline Nontrade tax & 105 & 114 & 119 & 133 & 132 & 127 & $\ldots$ \\
\hline International trade & 111 & 102 & 112 & 127 & 139 & 133 & $\ldots$ \\
\hline Nontax & 37 & 39 & 38 & 42 & 46 & 47 & 43 \\
\hline Capital revenue (land sales only) & 5 & 1 & 1 & 1 & 1 & 2 & 1 \\
\hline Grants & 13 & 10 & 17 & 11 & 10 & 4 & 11 \\
\hline $\begin{array}{l}\text { Total expenditure and net lending } \\
\text { Current }\end{array}$ & $\begin{array}{l}300 \\
234\end{array}$ & $\begin{array}{l}285 \\
241\end{array}$ & $\begin{array}{l}306 \\
259\end{array}$ & $\begin{array}{l}336 \\
276\end{array}$ & $\begin{array}{l}340 \\
275\end{array}$ & $\begin{array}{l}345 \\
276\end{array}$ & $\begin{array}{l}378 \\
308\end{array}$ \\
\hline $\begin{array}{l}\text { Current } \\
\text { Wages and salaries }\end{array}$ & $\begin{array}{l}234 \\
128\end{array}$ & $\begin{array}{l}241 \\
127\end{array}$ & $\begin{array}{l}259 \\
132\end{array}$ & $\begin{array}{l}276 \\
143\end{array}$ & $\begin{array}{l}275 \\
142\end{array}$ & $\begin{array}{l}276 \\
139\end{array}$ & $\begin{array}{l}308 \\
155\end{array}$ \\
\hline $\begin{array}{l}\text { Wages and salaries } \\
\text { Interest }\end{array}$ & $\begin{array}{r}128 \\
23\end{array}$ & $\begin{array}{r}121 \\
26\end{array}$ & $\begin{array}{r}132 \\
25\end{array}$ & $\begin{array}{r}143 \\
26\end{array}$ & $\begin{array}{r}142 \\
25\end{array}$ & $\begin{array}{r}139 \\
27\end{array}$ & $\begin{array}{r}155 \\
31\end{array}$ \\
\hline $\begin{array}{l}\text { Interest } \\
\text { Of which: foreign interest }\end{array}$ & $\begin{array}{l}23 \\
14\end{array}$ & 13 & $\begin{array}{l}25 \\
13\end{array}$ & $\begin{array}{l}20 \\
11\end{array}$ & 12 & $\begin{array}{l}21 \\
11\end{array}$ & 31 \\
\hline $\begin{array}{l}\text { Of which: foreign interest } \\
\text { Goods and services }\end{array}$ & 51 & & $\begin{array}{l}13 \\
53\end{array}$ & 11 & 12 & 11 & 14 \\
\hline & $\begin{array}{l}51 \\
32\end{array}$ & $\begin{array}{l}53 \\
35\end{array}$ & 53 & 64 & 64 & 62 & 68 \\
\hline Transfers & 32 & 35 & 49 & 43 & 44 & 48 & 54 \\
\hline Capital expenditure & 64 & 35 & 47 & 63 & 70 & 76 & 70 \\
\hline Net lending & 3 & 9 & 0 & -4 & -5 & -6 & 0 \\
\hline Current balance (before grants) & 18 & 15 & 9 & 26 & 41 & 31 & 36 \\
\hline Overall balance (above the line) & -30 & -18 & -19 & -22 & -13 & -32 & -22 \\
\hline Other 3/ & -11 & 1 & 0 & 19 & 0 & 14 & 0 \\
\hline Overall balance (cash basis) & -19 & -19 & -20 & -41 & -13 & -46 & -22 \\
\hline Of which: primary balance & 4 & 7 & 5 & -15 & 13 & -19 & 9 \\
\hline Identified financing & 19 & 19 & 20 & 41 & 13 & 46 & 22 \\
\hline Net external financing & 6 & 10 & 33 & 3 & 52 & 56 & 19 \\
\hline Disbursements & 17 & 21 & 46 & 20 & 65 & 77 & 43 \\
\hline Amortization & 11 & 11 & 13 & 16 & 13 & 21 & 25 \\
\hline Change in government foreign assets & 2 & 2 & 0 & 0 & 2 & 1 & 0 \\
\hline Net domestic financing & 12 & 7 & -14 & 37 & -43 & -11 & 4 \\
\hline Of which: banking system & 9 & 6 & -18 & 42 & -28 & -39 & $\ldots$ \\
\hline Exceptional financing & 0 & 0 & 1 & 1 & 1 & 1 & 0 \\
\hline \multicolumn{8}{|c|}{ (In percent of GDP, unless otherwise specified) } \\
\hline Total revenue and grants & 30.2 & 29.4 & 30.6 & 32.1 & 32.6 & 31.0 & 34.1 \\
\hline Of which: current revenue & 28.3 & 28.2 & 28.7 & 31.0 & 31.5 & 30.4 & 33.0 \\
\hline Total expenditure and net lending & 33.6 & 31.4 & 32.7 & 34.4 & 33.9 & 34.1 & 36.2 \\
\hline Current & 26.2 & 26.6 & 27.7 & 28.3 & 27.4 & 27.3 & 29.6 \\
\hline Wages and salaries & 14.3 & 14.1 & 14.2 & 14.6 & 14.1 & 13.8 & 14.9 \\
\hline Interest & 2.6 & 2.8 & 2.6 & 2.7 & 2.5 & 2.7 & 3.0 \\
\hline Goods and services & 5.7 & 5.9 & 5.7 & 6.6 & 6.4 & 6.1 & 6.5 \\
\hline Transfers & 3.6 & 3.8 & 5.2 & 4.5 & 4.4 & 4.7 & 5.2 \\
\hline Capital expenditure & 7.1 & 3.9 & 5.0 & 6.5 & 7.0 & 7.5 & 6.7 \\
\hline Net lending & 0.3 & 0.9 & 0.0 & -0.4 & -0.5 & -0.6 & 0.0 \\
\hline Other $3 /$ & -1.2 & 0.1 & 0.0 & 1.9 & 0.0 & 1.4 & 0.0 \\
\hline Current balance (before grants) & 2.1 & 1.6 & 1.0 & 2.6 & 4.1 & 3.1 & 3.4 \\
\hline Overall balance (above the line) & -3.4 & -2.0 & -2.1 & -2.3 & -1.3 & -3.2 & -2.2 \\
\hline Overall balance (cash basis) & -2.2 & -2.0 & -2.1 & -4.2 & -1.3 & -4.6 & -2.2 \\
\hline Of which: primary balance & 0.4 & 0.8 & 0.5 & -1.6 & 1.3 & -1.9 & 0.8 \\
\hline Net external financing & 0.6 & 1.1 & 3.5 & 0.3 & 5.2 & 5.5 & 1.8 \\
\hline Net domestic financing & 1.4 & 0.8 & -1.5 & 3.8 & -4.2 & -1.0 & 0.4 \\
\hline \multicolumn{8}{|l|}{ Memorandum items: } \\
\hline Gross central government debt, percent of GDP 4/ & 59.4 & 60.8 & 62.8 & 64.1 & 62.4 & 67.5 & 67.7 \\
\hline GDP at market prices, EC $\$$ millions & 892.1 & 905.7 & 935.2 & 975.0 & $1,003.2$ & $1,010.9$ & $1,042.3$ \\
\hline
\end{tabular}

Sources: Ministry of Finance and Planning; and Fund staff projections.

1/ Staff Report (4/1/04).

2/ The 2004 budget figures shown were modified from the actual budget to set grants and capital expenditures at historical averages. 3/ The difference between the overall balance as measured from above the line and from below the line (i.e., financing), which may include float and unidentified discrepancies.

4/ Net of intra-public sector debt (mainly central government debt to the NIS). 


\section{INTERNATIONAL MONETARY FUND}

EXTERNAL

Public Information Notice

RELATIONS

DEPARTMENT

Public Information Notice (PIN) No. 05/65

FOR IMMEDIATE RELEASE

May 19, 2005
International Monetary Fund

$70019^{\text {th }}$ Street, NW

Washington, D. C. 20431 USA

\section{IMF Executive Board Concludes 2003 Article IV Consultation with St. Vincent and the Grenadines}

On May 5, 2004 the Executive Board of the International Monetary Fund (IMF) concluded the Article IV consultation with St. Vincent and the Grenadines. ${ }^{1}$

\section{Background}

Following stagnation in 2001, a moderate recovery started in 2002. The economy is estimated to have grown $31 / 2$ percent in 2003. Growth has been supported by a rebound in agricultural production and expansionary fiscal policies, including large public sector investments, while private sector activity has been weak. Inflation has remained in the low single digits, reflecting the monetary discipline of the currency union. The 12-month inflation rate was 2.7 percent in November 2003. Unemployment has remained high (estimated at about 21 percent).

The overall fiscal stance in 2002-03 was relaxed, with the fiscal stimulus coming through a strong increase in investment partly offset by a higher current surplus of the central government due to a rise in revenue. The overall deficit of the Non-Financial Public Sector (NFPS) doubled to 4 percent of GDP a year over this period as capital spending — by public enterprises on power and water projects as well as by the central government-increased by an average of nearly 2 percentage points of GDP. As a consequence, public sector debt increased from about 69 percent of GDP in 2001 to more than 73 percent at end-2003.

\footnotetext{
${ }^{1}$ Under Article IV of the IMF's Articles of Agreement, the IMF holds bilateral discussions with members, usually every year. A staff team visits the country, collects economic and financial information, and discusses with officials the country's economic developments and policies. On return to headquarters, the staff prepares a report, which forms the basis for discussion by the Executive Board. At the conclusion of the discussion, the Managing Director, as Chairman of the Board, summarizes the views of Executive Directors, and this summary is transmitted to the country's authorities.
} 
In 2002-03, central government current revenue rose sharply while current expenditure was held under close control. One-off factors have contributed to the increase in revenue-notably around 1 percent of GDP from duty collections on the large imports of cell phones during 2003 following the liberalization of the telecommunications sector-but there have also been significant improvements in broadening the tax base, removing tax concessions, and strengthening tax administration. At the same time, government wages were kept frozen and non-wage expenditure was kept under tight control to maintain current expenditure largely unchanged.

The external current account deficit widened sharply in 2003 (to 16 percent of GDP from about $91 / 2$ percent in 2002) driven by a temporary spike in investment-related imports as well as the impact of higher international petroleum prices. About three quarters of the current account deficit during 2000-03 was financed by direct investment, while the remainder was financed by public sector borrowing. Merchandise exports and tourism receipts increased only marginally in 2003.

Regulation and supervision of the offshore sector continued to be strengthened. As a result, St. Vincent and the Grenadines was removed from the Financial Action Task Force (FATF) list of non-cooperative countries and territories (NCCTs) in June 2003 (it had been removed from the OECD's list of tax havens in 2002). The short-term consequence of strengthened regulation and supervision has been a sharp reduction in the number of offshore banks (which stood at 11 as of end-September 2003, compared with 44 at end-December 2001), although the reduction in government revenue from the sector has been modest because of an upward revision of fees.

The government has made some progress on structural reforms. Steps have been taken to diversify the economy and enhance its external competitiveness, attract foreign investment, improve the budgetary process, and strengthen the regulation of the financial sector.

\section{Executive Board Assessment}

Directors commended the authorities for the successful maintenance of macroeconomic stability despite a difficult economic environment. Directors noted that real growth in 2002-03 was above the average for the Eastern Caribbean Currency Union (ECCU) as a whole, supported by a rebound in agricultural production and expansionary fiscal policy. However, unemployment continued to be high and private sector activity remained weak.

Directors welcomed the substantial improvement in current revenue collections, which reflected not only one-off factors but also continued improvements in broadening the tax base, reducing tax concessions, and strengthening tax administration. The authorities were also commended for their efforts at containing current expenditure, particularly through the wage freeze in 2002-03 and tight control over outlays on other goods and services. Directors noted with some concern, however, the pursuit of a counter-cyclical fiscal policy, with a strong increase in investment expenditure, which had resulted in a weaker-than-expected fiscal outturn for 2003. 
Directors stressed the need to ensure fiscal discipline going forward. They encouraged the authorities to implement vigorously the envisaged tax reform measures, in particular the planned introduction of a value-added tax. Continued control over current expenditure, including through a prudent wage policy and civil service reform, will also be essential. Directors underlined that public sector investment should focus on key priority projects aimed at enhancing the economy's growth potential and should be financed largely on concessional terms. Continued efforts will also be necessary to strengthen the financial position of the public enterprises and improve their efficiency. Given uncertainties in the tourism sector and other potential exogenous shocks, Directors welcomed the authorities' commitment to pursue a cautious debt management strategy.

Directors noted that the key challenge over the medium term is to reinvigorate private sectorled growth and diversification of the economy, while preserving macroeconomic stability and ensuring fiscal sustainability. The development of a vibrant private sector should be promoted by addressing structural constraints to growth and competition in the economy. To this end, Directors underscored the importance of increased labor market flexibility and strengthened institutional capacity.

Directors commended the authorities for their ongoing efforts to strengthen the regulatory and supervisory framework of the financial system, including the offshore sector, as recommended by the Financial Sector Assessment Program (FSAP) for the ECCU. Nevertheless, they considered that more should be done to reduce risks. In particular, they saw an urgent need to develop and implement a clear strategy for restructuring the state-owned National Commercial Bank.

Directors noted that weaknesses in the statistical base hamper the quality of economic analysis and surveillance. They encouraged the authorities to address the data problems, including those related to the national accounts, balance of payments, and labor market.

Public Information Notices (PINs) form part of the IMF's efforts to promote transparency of the IMF's views and analysis of economic developments and policies. With the consent of the country (or countries) concerned, PINs are issued after Executive Board discussions of Article IV consultations with member countries, of its surveillance of developments at the regional level, of post-program monitoring, and of ex post assessments of member countries with longer-term program engagements. PINs are also issued after Executive Board discussions of general policy matters, unless otherwise decided by the Executive Board in a particular case. 
St. Vincent and the Grenadines: Selected Economic Indicators

(Annual percent changes, unless otherwise indicated)

\begin{tabular}{|c|c|c|c|c|c|}
\hline & 1999 & 2000 & 2001 & 2002 & 2003P \\
\hline \multicolumn{6}{|l|}{ Real sector } \\
\hline Nominal GDP at market prices & 4.1 & 1.5 & 3.3 & 4.3 & 3.7 \\
\hline Real GDP at factor cost & 3.6 & 2.0 & -0.1 & 1.4 & 3.6 \\
\hline Consumer prices (end of period) & -1.8 & 1.4 & -0.6 & 0.4 & 2.7 \\
\hline \multicolumn{6}{|l|}{ Public sector $1 /$} \\
\hline \multicolumn{6}{|l|}{ Central government finances } \\
\hline Revenue and grants & 30.2 & 29.4 & 30.6 & 32.1 & 31.0 \\
\hline Of which: current revenue & 28.3 & 28.2 & 28.7 & 31.0 & 30.4 \\
\hline Expenditures & 33.6 & 31.4 & 32.7 & 34.4 & 34.1 \\
\hline Current expenditures & 26.2 & 26.6 & 27.7 & 28.3 & 27.3 \\
\hline Capital expenditures & 7.1 & 3.9 & 5.0 & 6.5 & 7.5 \\
\hline Savings & 2.1 & 1.6 & 1.0 & 2.6 & 3.1 \\
\hline Overall balance & -2.2 & -2.0 & -2.1 & -4.2 & -4.6 \\
\hline \multicolumn{6}{|l|}{ Public sector finances } \\
\hline Public sector investment program & 14.7 & 7.1 & 8.6 & 10.1 & 11.0 \\
\hline Public sector savings & 5.1 & 5.1 & 4.5 & 5.6 & 5.7 \\
\hline Overall balance & -0.8 & -1.4 & -1.8 & -4.1 & -4.3 \\
\hline Public sector debt 2/ & 65.8 & 67.5 & 69.2 & 71.5 & 73.2 \\
\hline \multicolumn{6}{|l|}{ Money and interest rate $3 /$} \\
\hline Net domestic assets of the banking system & 5.5 & -1.7 & 7.2 & 5.4 & 23.6 \\
\hline Public sector & 2.1 & 1.9 & 0.3 & 4.8 & -3.8 \\
\hline Private sector & 11.5 & 8.0 & 2.1 & 4.3 & -6.1 \\
\hline Broad money & 12.5 & 9.5 & 3.0 & 8.3 & 1.9 \\
\hline Average weighted lending interest rate & 11.6 & 11.5 & 11.9 & 11.5 & 12.1 \\
\hline \multicolumn{6}{|l|}{ External sector $1 /$} \\
\hline External current account balance & -22.2 & -8.1 & -10.9 & -9.6 & -16.1 \\
\hline Public external debt & 48.5 & 47.8 & 49.1 & 47.1 & 51.4 \\
\hline Public external debt service 4/ & 6.5 & 5.7 & 6.7 & 6.5 & 7.1 \\
\hline $\begin{array}{l}\text { Real effective exchange rate (minus is } \\
\text { depreciation) } 5 /\end{array}$ & -0.1 & 5.1 & 0.5 & -7.2 & -13.4 \\
\hline
\end{tabular}

Sources: Eastern Caribbean Central Bank; Ministry of Finance and Planning; and IMF staff estimates and projections.

$1 /$ In percent of GDP.

2/ Net of intra-public sector debt (mainly central government debt to the NIS).

$3 /$ In relation to broad money at the beginning of the period.

4/ In percent of exports of goods and services.

$5 /$ The figure for 2003 is the 12-month change to October. 
Statement by Ian E. Bennett, Executive Director for St. Vincent and the Grenadines

May 5, 2004

Key Points

- Following a fairly subdued economic performance recently, real GDP rebounded in 2003.

- While the central government current surplus increased in 2003, the overall deficit widened consistent with higher spending on public investment.

- The authorities believe that the current exchange rate arrangements remain appropriate even though competitiveness in some sectors may have been affected.

- The authorities believe that the state has a critical role to play in fostering economic development, particularly when private sector activity is subdued.

- While cautious, the authorities are, nevertheless, optimistic that with a prudent approach, the adoption of timely reforms and a benign international environment, the medium term outlook is positive.

1. My authorities wish to convey their appreciation to the staff for the constructive input and support offered during the consultations. They broadly agree with the staff's assessment of the challenges and are optimistic about the medium term prospects following modest growth over the last two years.

\section{Recent Economic Developments and Outlook}

2. Following a subdued economic performance recently, economic growth rebounded in 2003. Real GDP for 2003, which had been expected to grow by 1.6 percent at the time of the Article IV consultation, is now estimated to have grown by 3.6 percent. My authorities are optimistic about this nascent recovery, which was supported by increased domestic demand. Increases in output of the non-traded sectors, particularly, construction, electricity and water and wholesale and retail trade reflected the higher domestic demand. In tourism, although total visitor arrivals was down marginally, modest growth was recorded in the important stay-over visitor category, while tourism receipts grew by $2^{1 / 2}$ percent. Despite a contraction in banana production, increased output from non-traditional crops was recorded, reflecting some early success of the agricultural diversification program.

3. While the central government current surplus increased to 4.1 percent of GDP in 2003 compared to 3.1 percent in 2002, higher capital spending to improve social and economic infrastructure and add productive capacity, resulted in a widening of the central government overall deficit. 
4. On the external account, the current account deficit widened, related to higher imports and a decline in banana export earnings. The higher imports were associated with new public investment and growth in the telecommunications sector, while the decline in banana export earnings reflected a combination of lower export volume and reduced prices.

5. My authorities are aware that much still needs to be done to ensure that the recovery is sustainable. They believe, however, that their economic reform efforts appear to be meeting with some success, and together with positive developments in the international economy, these should help improve the medium term economic outlook.

\section{Fiscal Policy}

6. While committed to fiscal prudence, my authorities' judgment on the pursuance of a counter-cyclical fiscal policy has been, by all reasonable assessments, largely successful. In particular, it has, to a large extent, managed to avert a full scale recession in 2001, and stemmed a rise in unemployment. Further, with the recovery over the last two years, the approach appears to have been an appropriate policy response given the economic circumstances.

7. My authorities agree with the staff that efforts to maintain control over current expenditure, including the government wage bill, are key to ensuring fiscal sustainability. The staff note that while these efforts have been largely successful, the government wage bill (as a percentage of GDP) has been higher than the average for the ECCU. While this is true, it must be noted that the higher wage bill reflects, in part, the fact that as a multi-island state, the government has to provide duplicate services to remote islands. At the same time, my authorities believe that the wage increases granted to public servants over the 2004-05 period was justified in order to preserve morale in the public service and retain qualified staff.

8. Efforts to broaden the tax base and enhance tax administration continue to bear fruit, contributing to higher revenue collections in 2003. The increase in revenue collections in 2003 also represented one-off factors, however, my authorities are committed to tax reform in order to bolster revenue and increase current savings. In this regard, preparatory work on the adoption of a VAT has commenced while the intention to revise the current property tax system to one that is market-based has been announced.

9. Total public sector debt at 72.9 percent of GDP in 2003 is amongst the lowest in the ECCU and is mostly concessional. My authorities are, however, aware of the need to contain debt service costs, and understand the potential impact that exogenous shocks could have. In this regard, they continue to pursue a prudent debt management strategy - for example, by substituting higher cost local loans with lower cost external financing and making use of cheaper financing on the Regional Government Securities Market (RGSM). At the same time, it is anticipated that with the write-off 
of part of a major loan and some rescheduling, public sector debt will fall to 67.1 percent of GDP in 2004, while debt service payments decline.

\section{Financial Sector Issues}

10. Development of a sound financial system with well-functioning supervisory arrangements is a key goal of my authorities. They acknowledge that there are gaps in the financial system as identified in the recent FSAP and are working steadfastly to address these issues. In conjunction with the ECCB, my authorities are updating the prudential regulations and supervisory system, restructuring weak financial institutions, and initiating reform of the financial laws and regulations. Amendments to the Banking Act and the Eastern Caribbean Central Bank Agreement Act, which gives the ECCB more authority to deal with problem banks, have been drafted, however, their introduction has been put on hold pending consideration of a more comprehensive amendment of the Banking Act expected to be completed during the first half of 2004.

11. In addition, new legislation has been introduced to modernize the system for the regulation of insurances, a supervisory and regulatory unit in the Ministry of Finance has been established to cover insurance companies, and the National Commercial Bank has been reorganized with a new Board of Directors and management has been strengthened.

12. The recent FSAP identified regulatory and supervisory weaknesses when measured against the Basel Core Principles and recommended the adoption of further antimoney laundering measures, particularly in the area of supervision and compliance. While my authorities intend to implement the general recommendations of the FSAP, there is disagreement with some of the findings in the Preliminary Draft BCP. In particular, my authorities believe there are factual inaccuracies and differences in the interpretation of the level of compliance in seven areas and would hope that these can be resolved speedily so that publication can be facilitated. In this regard, they are working with the assessors to incorporate suggested changes which will improve the accuracy of the reporting in the identified areas.

\section{Growth and Competitiveness}

13. The authorities believe that the current exchange rate arrangements remain appropriate even though competitiveness in some sectors may have been affected. The staff suggest that recent increases in the minimum wage may have affected competitiveness, however, it must be noted that the minimum wage in St.Vincent and the Grenadines is still amongst the lowest in the ECCU.

14. While acknowledging the role of the private sector in creating wealth, the authorities are convinced that the state has an important role to play in fostering economic development, particularly when the private sector activity remains subdued. In this regard, the policies of my authorities aim to support a more diversified economy 
which facilitates tourism, international financial and other services, and agriculture and fisheries as the main sectors.

15. My authorities disagree with the staff assessment that existing import licenses and price controls remain key hindrances to growth in the economy. Import licenses have been all but eliminated - except for a few items related to intra-regional trade and these are expected to be phased out next year, while price controls remain only on a couple of basic food items primarily for poverty reasons. Under these circumstances, my authorities believe these have little adverse impact on growth.

16. Improvements in labor market flexibility are also important to enhance growth prospects. Recognizing this, and consistent with efforts to establish the CARICOM Single Market and Economy (CSME), the authorities have already given the undertaking to remove the legal and administrative restrictions on labor mobility. This is expected to be completed in 2004.

\section{Conclusion}

17. Despite a difficult economic environment, prudent macroeconomic management has resulted in modest growth over the last two years. While cautious, the authorities are, nevertheless, optimistic that with a prudent approach, the adoption of timely reforms and a benign international environment, the medium term outlook is positive. The approach of the authorities over the medium term will, therefore, focus on sound macro-economic fundamentals, the pursuit of balanced growth and the recognition of social equity in its economic policy. 